\title{
1 Strong influence of trees outside forest in regulating microclimate 2 of intensively modified Afromontane landscapes
}

3 Iris J. Aalto ${ }^{1}$, Eduardo E. Maeda ${ }^{1}$, Janne Heiskanen ${ }^{1,2}$, Eljas K. Aalto ${ }^{3}$, Petri K. E. Pellikka ${ }^{1}$

$4 \quad{ }^{1}$ Department of Geosciences and Geography, University of Helsinki, P.O. Box 64, FI-00014, Helsinki, Finland

$5 \quad{ }^{2}$ Institute for Atmospheric and Earth System Research, Faculty of Science, University of Helsinki, Finland

$6{ }^{3}$ Department of Economics, Turku School of Economics, 20014 University of Turku, Finland

7 Correspondence to: Iris Aalto (iris.aalto@helsinki.fi)

9 Abstract. Climate change is expected to have detrimental consequences on fragile ecosystems, threatening biodiversity as well as food security of millions of people. Trees are likely to play a central role in mitigating these impacts. The microclimatic conditions below tree canopies usually differ substantially from the ambient macroclimate, as vegetation can buffer temperature changes and variability. Trees cool down their surroundings through several biophysical mechanisms, and the cooling benefits occur also with trees outside forest. The aim of this study was to examine the effect of canopy cover on microclimate in an intensively modified Afromontane landscape in Taita Taveta, Kenya. We studied temperatures recorded by 19 microclimate sensors under different canopy covers, and land surface temperature (LST) estimated by Landsat 8 thermal infrared sensor. We combined the temperature records with high-resolution airborne laser scanning data to untangle the combined effects of topography and canopy cover on microclimate. We developed four multivariate regression models to study the joint impacts of topography and canopy cover on LST. The results showed a negative linear relationship between canopy cover percentage and daytime mean $\left(R^{2}=0.65\right)$ and maximum $\left(R^{2}=0.75\right)$ temperatures. Any increase in canopy cover contributed to reducing temperatures. The average difference between $0 \%$ and $100 \%$ canopy cover sites was $5.7{ }^{\circ} \mathrm{C}$ in mean temperatures and $10.2{ }^{\circ} \mathrm{C}$ in maximum temperatures. Canopy cover reduced LST on average by $0.05{ }^{\circ} \mathrm{C} / \% \mathrm{CC}$. The influence of canopy cover on microclimate was shown to vary strongly with elevation and ambient temperatures. These results demonstrate that trees have substantial effect on microclimate, but the effect is dependent on macroclimatic conditions, highlighting the importance of maintaining tree cover particularly in warmer conditions. Hence, we demonstrate that trees outside forests can increase climate change resilience in fragmented landscapes, having strong potential for regulating regional and local temperatures.

\section{Keywords}


https://doi.org/10.5194/bg-2021-261

Preprint. Discussion started: 21 October 2021

(c) Author(s) 2021. CC BY 4.0 License.

\section{Introduction}

32 Climate change poses an imminent threat to the rich biodiversity and frequently found fragile socio-economic conditions

33 that characterize Afromontane ecosystems and their surroundings. In these regions, climate warming is mostly driven by

34 land use and land cover change (LULCC) (IPCC, 2018; Pellikka and Hakala, 2019; Abera et al., 2020). Agricultural

35 expansion, in particular, has caused rapid loss of tropical forests (FAO, 2016). Forests are essential in mitigating climate

36 warming, due to their role in especially the carbon and water cycles (Beer et al. 2010; Ellison et al. 2017; De Frenne et

37 al. 2019).

38 Currently, forests cover approximately 4 billion hectares of the Earth's surface (FAO, 2016). Trees that are not part of a

39 forest are commonly called "trees outside forest" (TOF) and, by the definition of FAO (2000), include trees on farmland,

40 in cities, and in other locations not defined as forest. Forests and TOF provide vital ecosystem services including water

41 regulation, air purification, carbon sequestration, and climate regulation. They are also a source of goods for humans

42 (Martínez Pastur et al., 2018). Many ecosystem services, such as nutrient cycling and pollination, occur in the

43 understories, where tree canopies create the appropriate microclimates essential for these processes (De Frenne et al.,

44 2013). The term "microclimate" describes the climatic conditions near the ground or along the vertical forest profile, with

45 a scale from centimeters to meters (Zellweger et al., 2019). In contrast to free air temperatures, which are highly controlled

46 by elevation and atmospheric processes, temperatures close to the ground are primarily affected by topographic factors

47 and vegetation structures that produce local microclimates through shading, mixing of air, and evapotranspiration (Das et

48 al., 2015; Zellweger et al., 2020). Climatic conditions below forest canopies can differ substantially from the ambient

49 macroclimate. Furthermore, they can vary spatially within the forest (Chen et al., 1999). This variability has different

50 magnitudes at different latitudes: for example, tropical forests experience the strongest cooling effect (Li et al., 2015;

51 Wanderley et al., 2019). The temperature buffering provided by tree cover may protect ecosystems from climate change

52 consequences (Zomer et al., 2016; Ellison et al., 2017; De Frenne et al., 2019; Wanderley et al., 2019), but the magnitude

53 of the buffering is affected by the forest area (Ewers and Banks-Leite, 2013). In time, forest microclimates will likely

54 warm like the macroclimate around them, and fragmentation may accelerate this process (Ewers and Banks-Leite, 2013;

55 Li et al., 2016).

56 Studies about forests' response to climate warming have primarily focused on the macroscale, despite wide recognition

57 of the vital role microclimates play (Belsky et al., 1989; De Frenne et al., 2019). Further, microclimate may be a better

58 indicator of how well forests mitigate climate change than macroclimate (De Frenne et al., 2013). Due to the importance

59 of microclimatic conditions for the survival of tropical species facing climate change, below-canopy microclimates

60 warrant further investigation (Jucker et al., 2018). 
https://doi.org/10.5194/bg-2021-261

Preprint. Discussion started: 21 October 2021

(c) Author(s) 2021. CC BY 4.0 License.

(2)

61 However, microclimatic studies require extensive field measurements, making them sometimes unpractical or imprecise

62 in larger scale applications (Prata et al., 1995). Alternatively, measuring satellite-derived land surface temperature (LST)

63 proves useful when point-wise field measurements are insufficient, given the high spatial coverage of spaceborne LST

64 and the strong correlation between LST and air temperature (Jin and Dickinson, 2010; Li et al., 2013). However, LST

65 cannot provide information in the smallest relevant scales, such as organism level (Potter et al., 2013; Jucker et al., 2018).

66 Due to the various factors affecting LST, accurate estimation remains a challenge (Simó et al., 2018; Li et al., 2013).

67 Nevertheless, the complexity of the issue with climate change requires attention at both spatial resolutions.

68 In remote sensing of vegetation, common outputs in previous research are land cover and land use types or vegetation

69 indices, such as the normalized vegetation index (NDVI) or leaf area index (LAI) (Nemani et al., 1993; Kim 2013; He et

70 al., 2019). However, airborne laser scanning (ALS) has proven to be a more effective method for computing structural

71 variables, such as above-ground biomass, canopy height, and canopy cover (Griffin et al., 2008; Heiskanen et al., 2015a;

72 Heiskanen et al., 2015b; Pellikka et al., 2018; Jucker et al., 2018). Canopy cover (CC) describes the proportion of the

73 forest floor covered by the vertical projection of the tree crowns (Korhonen et al., 2006) and it is the most important

74 variable used in defining forests or other land with tree cover (FAO, 2015). ALS can assess tree cover over large areas

75 more precisely than field measurements can. Hence, when ALS is combined with either field-based or remotely sensed

76 temperatures, we can study the influence of trees on temperature in a new way of that is both nuanced and large scale.

77 The primary objective of this study was to examine how different levels of CC can contribute to lower temperatures and

78 more stable microclimates across a highly heterogeneous Afromontane landscape in Kenya. We based our analysis on

79 micro-climatological measurements and CC estimates retrieved from ALS data. Microclimate sensors cannot entirely

80 capture the spatial variability of temperatures, especially in heterogeneous landscapes. Therefore, we used satellite

81 thermal data to provide a comprehensive and spatially continuous representation of the relationship between CC and

82 temperature

83

\section{Materials and methods}

\section{$85 \quad 2.1$ Study area}

86 The Taita Hills are located in the Taita-Taveta County in the Coast Province in southern Kenya, approximately $200 \mathrm{~km}$

87 from Mombasa and $360 \mathrm{~km}$ from the capital city Nairobi. The study area comprises of the Taita Hills and the lowland

88 areas of Maktau, LUMO Community Wildlife Sanctuary and Taita Hills Wildlife Sanctuary that have been laser scanned

89 by University of Helsinki (Fig. 1). The elevation in the study area varies from $640 \mathrm{~m}$ in the lowlands to the highest peak 
https://doi.org/10.5194/bg-2021-261

Preprint. Discussion started: 21 October 2021

(c) Author(s) 2021. CC BY 4.0 License.

90 of the hills, Vuria, at $2208 \mathrm{~m}$. Climate is mainly semi-arid. According to the Kenya Ministry of Agriculture, Livestock

91 and Fishery (MoALF), annual precipitation averages $650 \mathrm{~mm}$, but differences between hills and lowlands are notable:

92 lowlands receive $500 \mathrm{~mm}$ annually compared to $1500 \mathrm{~mm}$ in the hills. Two rainy seasons control the climate and growing

93 seasons: long rains from March to June, and short rains from October to December (Pellikka et al., 2013), while months

94 from January to March are a short hot dry season and months from June to October long cool dry season (Wachiye et al.,

95 2020). Mean temperature in the lowlands is $23{ }^{\circ} \mathrm{C}$ and in the hills $18{ }^{\circ} \mathrm{C}$ (MoALF, 2016). Vegetation varies from dry

96 savanna and shrubland in the lowlands dominated by Vachellia ssp. and Commiphora ssp. tree species to indigenous

97 cloud forests in the hilltops. Small indigenous forest fragments, exotic tree plantations, and intensive agriculture dominate

98 the landscape in the hills. Agroforestry practices are typical, which increases cropland CC. TOF make up a remarkable

99 amount of the area's total aboveground carbon and play an important part in carbon sequestration in the area (Pellikka et

100 al., 2018), especially because Taita Hills have experienced massive indigenous forest loss since 1950's (Pellikka et al.,

101 2009). Forest loss is a major threat to biodiversity, as Taita Hills are identified as an important biodiversity hotspot

102 (Pellikka et al., 2013; Thijs et al., 2015).

103 With climate change, temperatures in Kenya are expected to increase by $2-4{ }^{\circ} \mathrm{C}$ by the end of the century (Adhikari et

104 al., 2015), and changes in precipitation, that will increase the moisture stress of crops, are projected (MoALF, 2016). Dry

105 spells, heat stress and extreme rain events pose a threat to the area's agricultural production. These phenomena cause crop

106 failure and low yields, and hence affect the livelihoods of people (Adhikari et al., 2015; MoALF 2016). Farmers in the

107 area have already noticed climate fluctuations that affect both crops and livestock (Mwalusepo et al., 2015). 
https://doi.org/10.5194/bg-2021-261

Preprint. Discussion started: 21 October 2021

(c) Author(s) 2021. CC BY 4.0 License.

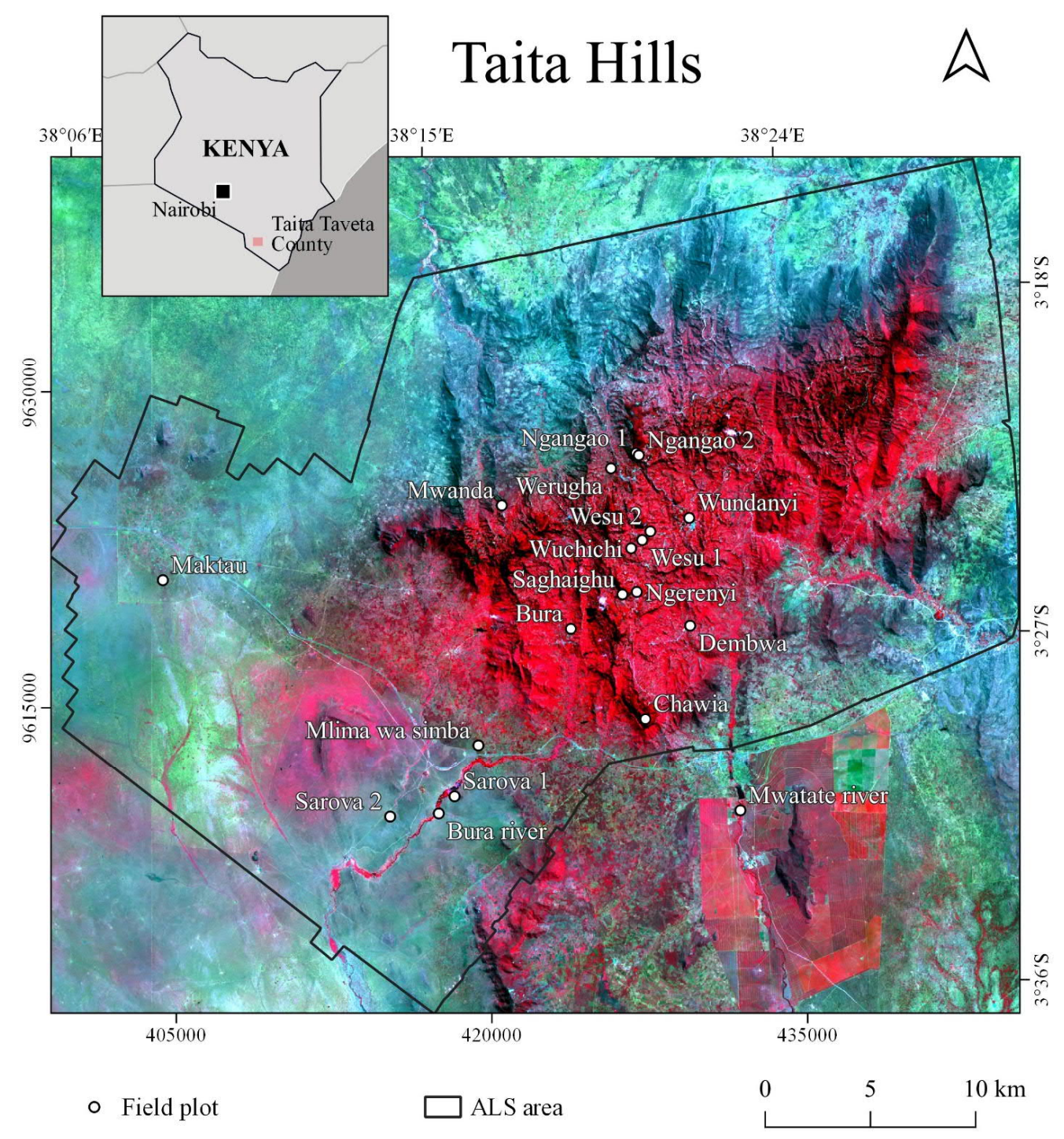

109 Figure 1: Field plots with microclimate sensors in Taita Taveta County, Kenya. The base map is a false color Landsat 8

110 OLI image from July 4, 2019.

111

$112 \quad 2.2$ Airborne laser scanning data 
https://doi.org/10.5194/bg-2021-261

Preprint. Discussion started: 21 October 2021

(c) Author(s) 2021. CC BY 4.0 License.

113 We applied an ALS-based Digital Elevation Model (DEM) raster at $1 \mathrm{~m}$ resolution and a CC raster at $30 \mathrm{~m}$ resolution.

114 The ALS data for the hills were acquired in February 2014 and February 2015, and the data for lowland areas in March

115

116

117

118

119

120

121 2014. The mean pulse density of the ALS data in the hills was 3.1 pulses $/ \mathrm{m}^{-2}$ and mean return density 3.4 returns $/ \mathrm{m}^{-2}$, for the lowlands the pulse density was 1.04 pulses $/ \mathrm{m}^{-2}$. The ALS data used in this study are described in detail in Adhikari et al. (2017) and Amara et al. (2020) with the description of pre-processing and derivation of DEM and CC rasters.

We resampled the DEM to $30 \mathrm{~m}$ resolution to fit to the spatial resolution of the Landsat 8 image, and utilized it to derive topographic factors slope degree $\left(^{\circ}\right)$ and aspect $\left(^{\circ}\right)$ using ArcGIS Pro spatial analyst tools.

\subsection{Microclimatological field measurements}

Based on the CC raster derived from the ALS data, we selected a total of 19 field plots representing different CC levels (Table 1). In the plots, we installed TOMST TMS-4 microclimate sensors to measure temperature at three different heights: soil at $6 \mathrm{~cm}$ below ground, surface at $2 \mathrm{~cm}$ above ground, and air temperature at $15 \mathrm{~cm}$ above ground $\left(\mathrm{T}_{\text {soil, }}, \mathrm{T}_{\text {surface }}\right.$ and $\mathrm{T}_{\text {air }}$, respectively) (Wild et al., 2019) from June 13 to July 10, 2019. The sensors measured parameters every 15 minutes. We calculated daytime temperature aggregates between sunrise and sunset, local time 06.30-18.30 UTC $+3 \mathrm{~h}$. We calculated maxima as the mean of daily maxima, and minimum temperatures as the mean of minimum temperatures based on the 24 hour cycle.

To isolate the influence of $\mathrm{CC}$ on microclimate, we quantified and later removed the effect of topography, such as elevation $(\mathrm{m})$ and slope $\left(^{\circ}\right)$, on temperature. We examined the relationships between the variables first with Pearson's correlation using elevation, slope and CC as explanatory variables in a multiple regression model. Elevation and CC were the only statistically significant variables. We corrected the daytime mean temperatures according to the altitudinal lapse rates, which were $7.26^{\circ} \mathrm{C} \mathrm{km}^{-1}$ for soil temperature $\left(\mathrm{T}_{\text {soil }}\right), 8.09{ }^{\circ} \mathrm{C} \mathrm{km}^{-1}$ for surface temperature $\left(\mathrm{T}_{\text {surface }}\right)$ and $8.06{ }^{\circ} \mathrm{C} \mathrm{km}^{-}$

${ }^{1}$ for air temperature $\left(T_{\text {air }}\right)$. In the case of diurnal analysis, we applied separate lapse rates for each hour. These varied from $6.1{ }^{\circ} \mathrm{C}$ to $8.2{ }^{\circ} \mathrm{C} \mathrm{km}^{-1}$ in $\mathrm{T}_{\text {soil }}, 3.8{ }^{\circ} \mathrm{C}$ to $10.4{ }^{\circ} \mathrm{C} \mathrm{km}^{-1}$ in $\mathrm{T}_{\text {surface }}$ and $3.3{ }^{\circ} \mathrm{C}$ to ${ }^{\circ} \mathrm{C} \mathrm{km}^{-1}$ in $\mathrm{T}_{\text {air. }}$ To find the relationships between temperature, $\mathrm{CC}$ and topographic variables, we conducted statistical analysis, including descriptive statistics, linear regression and Pearson's correlation. We used RStudio (R Core Team, 2019) for all statistical analysis.

Because the ALS data was 4-5 years older than the field measurements, we acquired hemispherical photography at each field plot for validating the CC raster. Moreover, the ALS data was collected during the short dry season, in contrast to the field measurements, which we carried out during the start of long dry season in June 2019. For Mwatate river plot, CC was retrieved by hemispherical photography only, as the plot was laying outside of the ALS coverage. The methodology is described in the supplementary material. 
https://doi.org/10.5194/bg-2021-261

Preprint. Discussion started: 21 October 2021

(c) Author(s) 2021. CC BY 4.0 License.

\begin{tabular}{|c|c|c|c|}
\hline Site & $\mathrm{CC} \%$ & Elevation, $\mathrm{m}$ & Description \\
\hline Bura & 68 & 1095 & Parkland by school campus \\
\hline Bura river & 79 & 880 & Riverine forest \\
\hline Chawia & 97 & 1562 & Indigenous forest \\
\hline Dembwa & 13 & 1083 & Agroforestry \\
\hline Maktau & 19 & 1044 & Bushland \\
\hline Mlima wa simba & 8 & 923 & Bushland \\
\hline Mwanda & 2 & 1653 & Bushland \\
\hline Mwatate river & 63 & 884 & Riverine forest \\
\hline Ngangao 1 & 94 & 1775 & Indigenous forest \\
\hline Ngangao 2 & 77 & 1778 & Eucalyptus forest \\
\hline Ngerenyi campus & 44 & 1572 & Macadamia plantation \\
\hline Saghaighu & 16 & 1611 & Agroforestry \\
\hline Sarova 1 & 0 & 901 & Bushland \\
\hline Sarova 2 & 0 & 900 & Grassland \\
\hline Werugha & 8 & 1613 & Macadamia plantation \\
\hline Wesu 1 & 53 & 1642 & Forest edge \\
\hline Wesu 2 & 0 & 1562 & Open maize field \\
\hline Wuchichi & 36 & 1595 & Agroforestry \\
\hline Wundanyi & 31 & 1372 & Riverside bushland \\
\hline
\end{tabular}

142 Table 1: Names, canopy cover (CC) percentages, elevations and descriptions of field plot sites.

\section{$143 \quad 2.4$ Land Surface Temperature}

144 To observe the effect of CC on temperature in Taita Taveta County, we applied Landsat 8 OLI thermal infrared sensor

145 (TIRS) satellite image data, downloaded from USGS Earth Explorer (https://earthexplorer.usgs.gov/). The bands 10 and

14611 of TIRS provide thermal infrared imagery in a resolution of $100 \mathrm{~m}$, but we resampled the band to $30 \mathrm{~m}$ to concert with

147 the OLI images. The image used in the study was a Level-1 scene obtained on July 4, 2019 at approximately 10:30 UTC

$148+3 \mathrm{~h}$ with solar azimuth angle of $45.6^{\circ}$ and solar elevation angle of 52.1 ${ }^{\circ}$. The cloud cover of the whole scene was 11.67

$149 \%$; there was no completely cloudless scene over the study area for the timing of the field measurements.

150 Several methods have been developed to retrieve LST from Landsat 8. Unfortunately, shortly after the launch of Landsat

1518 in 2013, a stray light problem was detected with TIRS band 11, and it was not recommended by United States Geological 
152

Survey (USGS) to apply for scientific purposes (USGS, 2017). In order to result in a topographically corrected LST product, we applied the workflow by Ndossi and Avdan (2016) (Fig. 2). We used the single channel (SC) method by Jiménez-Muñoz and Sobrino (2003) to calculate LST, because SC method needs only one thermal infrared channel, and land surface emissivity and water vapor content as parameters. The SC formula is shown in Eq. (1):

$$
T_{s}=\gamma\left[\frac{1}{\varepsilon}\left(\Psi_{1} L_{s e n}+\Psi_{2}\right)+\Psi_{3}\right]+\delta
$$

$$
\gamma=\frac{T_{s e n}^{2}}{b_{\gamma} L_{s e n}}
$$

$$
\delta=T_{\text {sen }}-\frac{T_{s e n}^{2}}{b_{\gamma}}
$$

where Ts = LST, $\gamma=$ parameter depending on Eq. (2), $\delta=$ parameter depending on Eq. (3), $\varepsilon=$ land surface emissivity, $L_{\text {sen }}=$ top of atmosphere spectral radiance $\left(\mathrm{W} \mathrm{sr}^{-1} \mathrm{~m}^{-2} \mu \mathrm{m}^{-1}\right), b \gamma=1324 \mathrm{~K}$ for Landsat 8 band 10 , and $T_{\text {sen }}=$ at sensor brightness temperature (K). We obtained the atmospheric parameters $\Psi 1, \Psi 2$ and $\Psi 3$ with Eq. (4):

$$
\left[\begin{array}{l}
\Psi_{1} \\
\Psi_{2} \\
\Psi_{3}
\end{array}\right]=\left[\begin{array}{lll}
c_{11} & c_{12} & c_{13} \\
c_{21} & c_{22} & c_{23} \\
c_{31} & c_{32} & c_{33}
\end{array}\right]\left[\begin{array}{c}
\omega^{2} \\
\omega \\
1
\end{array}\right]
$$

According to Jiménez-Muñoz, et al. (2014), the coefficients for atmospheric parameters for Landsat 8 TIRS are as in Eq. (5):

$$
c=\left[\begin{array}{llr}
0.04019 & 0.02916 & 1.01523 \\
-0.38333 & -1.50294 & 0.20324 \\
0.00918 & 1.36072 & -0.27514
\end{array}\right]
$$

We conducted similar topographic correction with the Landsat image as with microclimate sensors to exclude the effect of topography on LST. Topographic variables (elevation, slope and aspect), CC and LST were included in a multiple regression model. We classified aspect to nine classes indicating eight cardinal directions (south, south-west, west, northwest, north, north-east, east, south-east), and flat surface. The classes were treated as dummy variables due to their categorical nature. Following Wanderley et al. (2019), we calculated the topographically corrected LST with Eq. (6):

$$
T^{\prime}=T-\Delta T h-\Delta T s-\Delta T a
$$

Where T' = topographically corrected LST, T = raw LST, $\Delta \mathrm{Th}=$ difference of $\mathrm{T}$ to the reference $\mathrm{LST}$ at elevation of 880 $\mathrm{m}, \Delta \mathrm{Ts}=$ difference of $\mathrm{T}$ to the reference LST at slope of $0^{\circ}, \Delta \mathrm{Ta}=$ difference of $\mathrm{T}$ to the reference LST in the aspect class "north". We used linear regression to study how much CC percentage and topographic variables affected microclimate and LST. In total, we estimated four different models for LST (Table 2). 


\author{
Model Predictors \\ 1 DEM, CC, slope, aspect (south, south-west, west, north-west, north, north-east, east, south-east) \\ 2 DEM, CC, slope, aspect (south, south-west, west, north-west, north, north-east, east, south-east) \\ elevation zones ( $<1000 \mathrm{~m}, 1000-1500 \mathrm{~m},>1500 \mathrm{~m})$, elevation zones * CC \\ 3 DEM, CC, slope, aspect (south, south-west, west, north-west, north, north-east, east, south-east), DEM \\ $* \mathrm{CC}$ \\ 4 DEM, CC, slope, aspect (south, south-west, west, north-west, north, north-east, east, south-east), \\ elevation zones ( $<1000 \mathrm{~m}, 1000-1500 \mathrm{~m},>1500 \mathrm{~m})$, elevation zones * CC, aspect classes * CC
}

Table 2: Topographic and canopy cover (CC) predictors included in the four multiple regression models used in the analysis of Landsat 8 Land surface temperature.
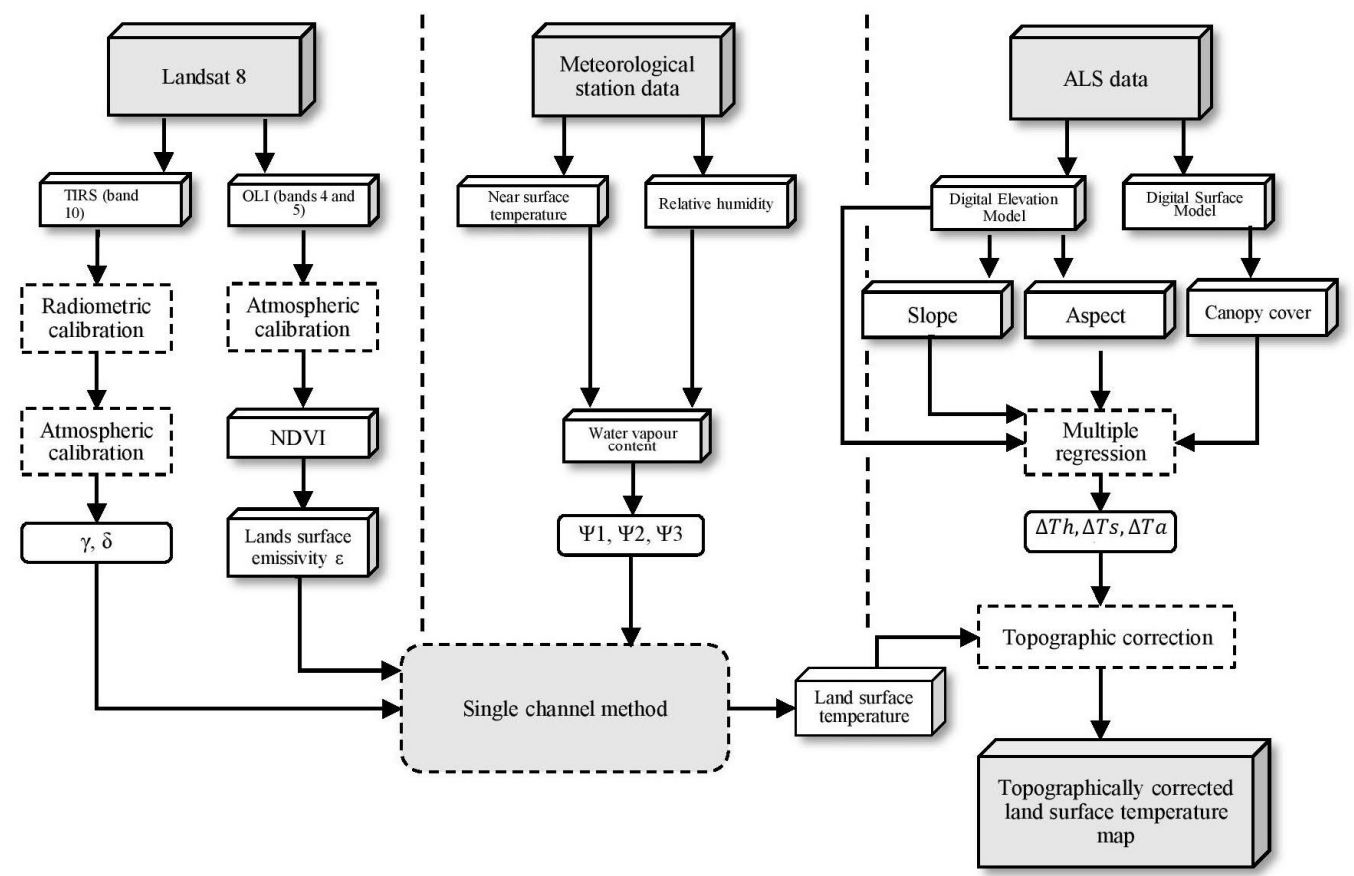

179 Figure 2: The workflow of Landsat 8 processing following the methodology by Ndossi and Avdan (2016), and 
https://doi.org/10.5194/bg-2021-261

Preprint. Discussion started: 21 October 2021

(c) Author(s) 2021. CC BY 4.0 License.

(c) (i)

181

182 3. Results

$183 \quad 3.1$ Canopy cover and microclimate

$184 \quad$ 3.1.1 Temporal variation

185 Figure 3 presents the daily variation in topographically corrected daytime mean temperatures (T'). The effect of CC was

186 evident at all three measurement heights (soil, surface, air): mean temperatures were lower in high CC sites than in open

187 areas, yet some low CC sites exhibited relatively low temperatures. On the hottest day of the study period (July 2),

188 temperature differences between the hottest (Maktau, 19\% CC) and coolest (Ngangao 1, 94\% CC) sites were $11.0^{\circ} \mathrm{C}$ in

$189 \mathrm{~T}^{\prime}$ soil, $11.3^{\circ} \mathrm{C}$ in $\mathrm{T}^{\prime}$ surface and $9.8^{\circ} \mathrm{C}$ in $\mathrm{T}{ }_{\text {air. }}$. Even during colder days, temperatures were approximately $6.5^{\circ} \mathrm{C}$ lower in

190 sites with dense canopies than in open land.

191 CC affected also temperature variability: SD of temperature decreased by approximately 0.1 per $10 \mathrm{CC} \%$ increase at all

192 measurement heights. Especially T' ${ }_{\text {soil }}$ in the sites with high CC remained relatively stable from day to day, showing little

193 fluctuation even during the hot day streaks: differences remained even less than $1{ }^{\circ} \mathrm{C}$ between hottest and coolest days.

194 When comparing the three measurement heights, the coldest mean temperatures were measured in $\mathrm{T}^{\prime}{ }_{\text {air }}$ and the hottest in

$195 \mathrm{~T}^{\prime}$ 'surface. Temperatures varied more in $\mathrm{T}^{\prime}$ 'surface $(\mathrm{SD}=3.0)$ and $\mathrm{T}^{\prime}$ air $(\mathrm{SD}=2.7)$ than in $\mathrm{T}^{\prime}$ soil $(\mathrm{SD}=2.3)$. 
https://doi.org/10.5194/bg-2021-261

Preprint. Discussion started: 21 October 2021

(c) Author(s) 2021. CC BY 4.0 License.

(c) (i)

(a)

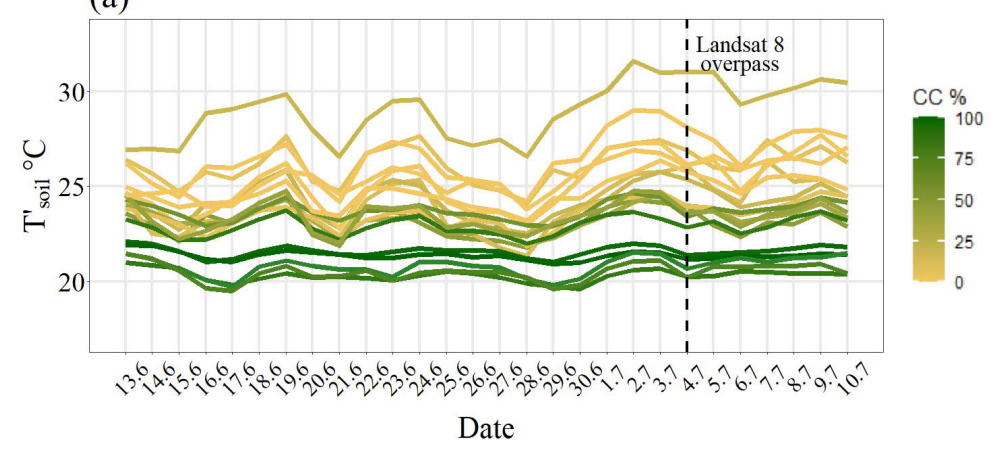

(b)

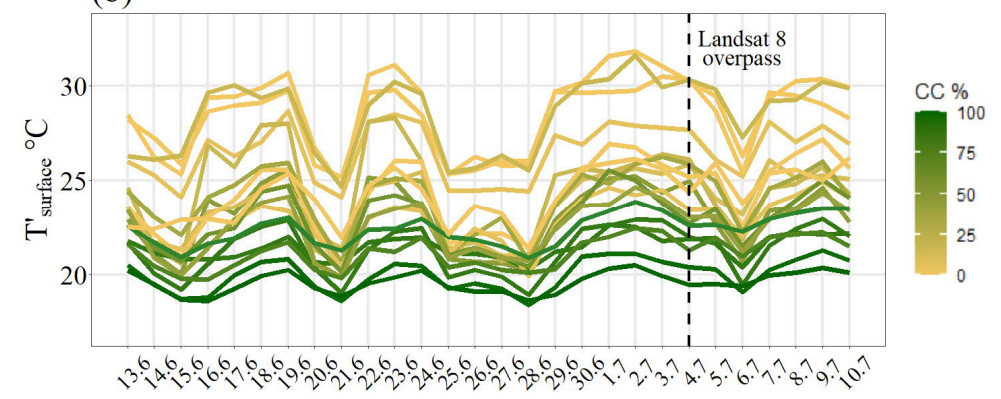

Date

(c)

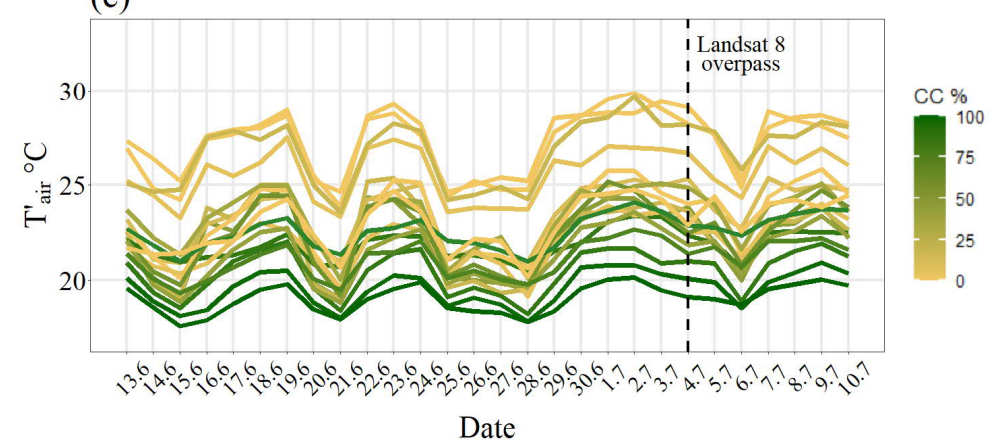

Figure 3: Daily variation in topographically corrected daytime (6.30-18.30) mean temperatures (T') between June 13 and July 10, 2019. Line color indicates canopy cover (CC) percentage. Dashed line represents the overpass date of Landsat 8, July 4, 2019. a) Soil temperature. b) Surface temperature. c) Air temperature.

200 Figure 4 shows the intra-daily temperature variability based on study period means. T' ${ }^{\prime}$ soil were more stable than T' surface

201 and T' air that showed higher peaks and drops. In the morning, temperatures at all measurement heights started to rise

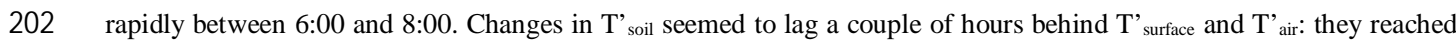

203 highest readings between 11:00 and 15:00, while $\mathrm{T}^{\prime}$ soil peaked between 15:00 and 17:00. Further, after peaking, 
Figure 4 also describes the correlation between $\mathrm{CC} \%$ and temperatures. The impact of $\mathrm{CC}$ was the lowest in the morning,
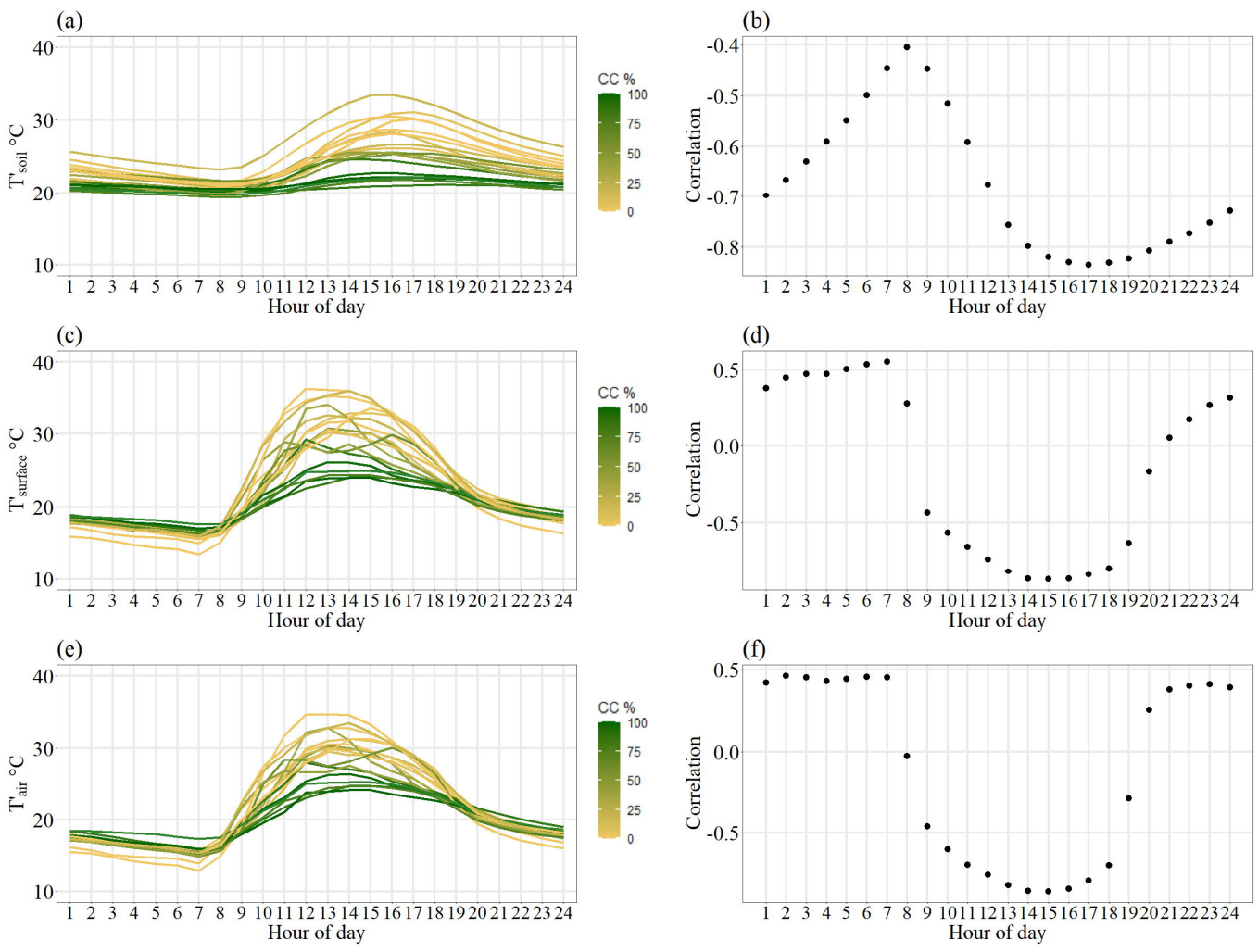

Figure 4: Topographically corrected diurnal mean temperatures (T') (left) and the correlation between T' and canopy cover (CC) percentage (right) between June 13 and July 10, 2019. Hour refers to ordinal number of hour, e.g. 1 means 00:00-01:00. Line color indicates CC percentage. a-b) Soil temperature. c-d) Surface temperature. e-f) Air temperature.

\subsubsection{Mean, maximum and minimum temperatures}

Mean temperatures had significant negative correlation with CC at all the measurement heights ( $\mathrm{T}^{\prime}$ surface and $\mathrm{T}^{\prime}$ air $r=$ $0.84, \mathrm{~T}^{\prime}$ soil $\left.r=-0.78\right)$. Based on the linear regression, an increase from $0 \%$ to $100 \% \mathrm{CC}$ decreased $\mathrm{T}^{\prime}$ soil by $5.2{ }^{\circ} \mathrm{C}\left(R^{2}=\right.$ 

and T' ${ }_{\text {air }}$ was $5.7^{\circ} \mathrm{C}\left(R^{2}=0.65\right) . \mathrm{T}^{\prime}$ 'surface and $\mathrm{T}^{\prime}$ air were in general higher than $\mathrm{T}^{\prime}$ soil, which was a case also with temperature maxima. sites experienced the lowest $\mathrm{T}^{\prime}$ 'surface and $\mathrm{T}^{\prime}$ air maxima, while $\mathrm{T}^{\prime}$ 'surface and $\mathrm{T}^{\prime}$ 'air were the hottest in Maktau and sites with zero $\% \mathrm{CC}$. Here, average maximum temperatures ranged between $30{ }^{\circ} \mathrm{C}$ and $38.5^{\circ} \mathrm{C}$. The linear models showed that the increase from zero \% $\mathrm{CC}$ to $100 \% \mathrm{CC}$ decreased the maximum $\mathrm{T}$ ' ${ }_{\text {soil }}$ by $9{ }^{\circ} \mathrm{C}\left(R^{2}=0.69\right)$, $\mathrm{T}^{\prime}$ surface by $12.1{ }^{\circ} \mathrm{C}\left(R^{2}=0.74\right)$ and $\mathrm{T}^{\prime}$ air by $9.6^{\circ} \mathrm{C}\left(R^{2}=0.69\right)$ (Table 3$)$. On average, the difference was $10.2{ }^{\circ} \mathrm{C}$. Based on the model coefficients, which indicate the magnitude of the influence of $\mathrm{CC}$ on temperature, the cooling effect of $\mathrm{CC}$ was stronger on maximum $\mathrm{T}^{\text {' }}$ soil and $\mathrm{T}_{\text {'surface }}$ than mean, while $\mathrm{CC}$ affected $\mathrm{T}$ ' air mean more than maximum.
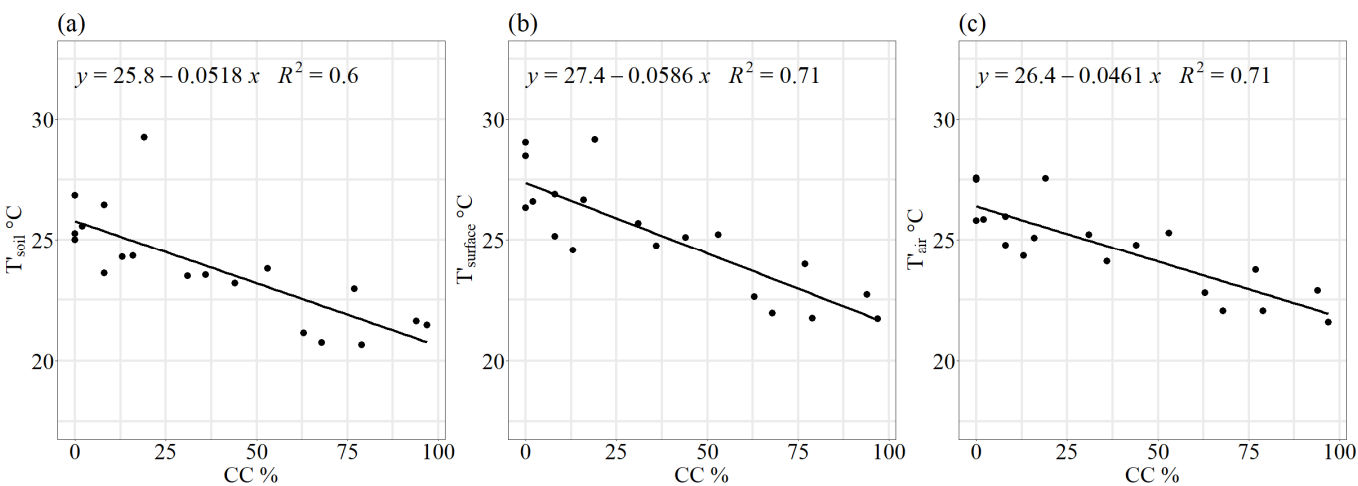

Figure 5: Scatterplots of topographically corrected daytime mean temperatures (T’) against canopy cover (CC) percentage, with regression line. a) Soil temperature. b) Surface temperature. c) Air temperature.

Minimum temperatures showed no explicit relationship with $\mathrm{CC}$, and sites with similar $\mathrm{CC} \%$ had high temperature variability. $R^{2}$ were low $(<0.2)$ at all measurement heights, and correlations between temperatures and $\mathrm{CC}$ were insignificant. 


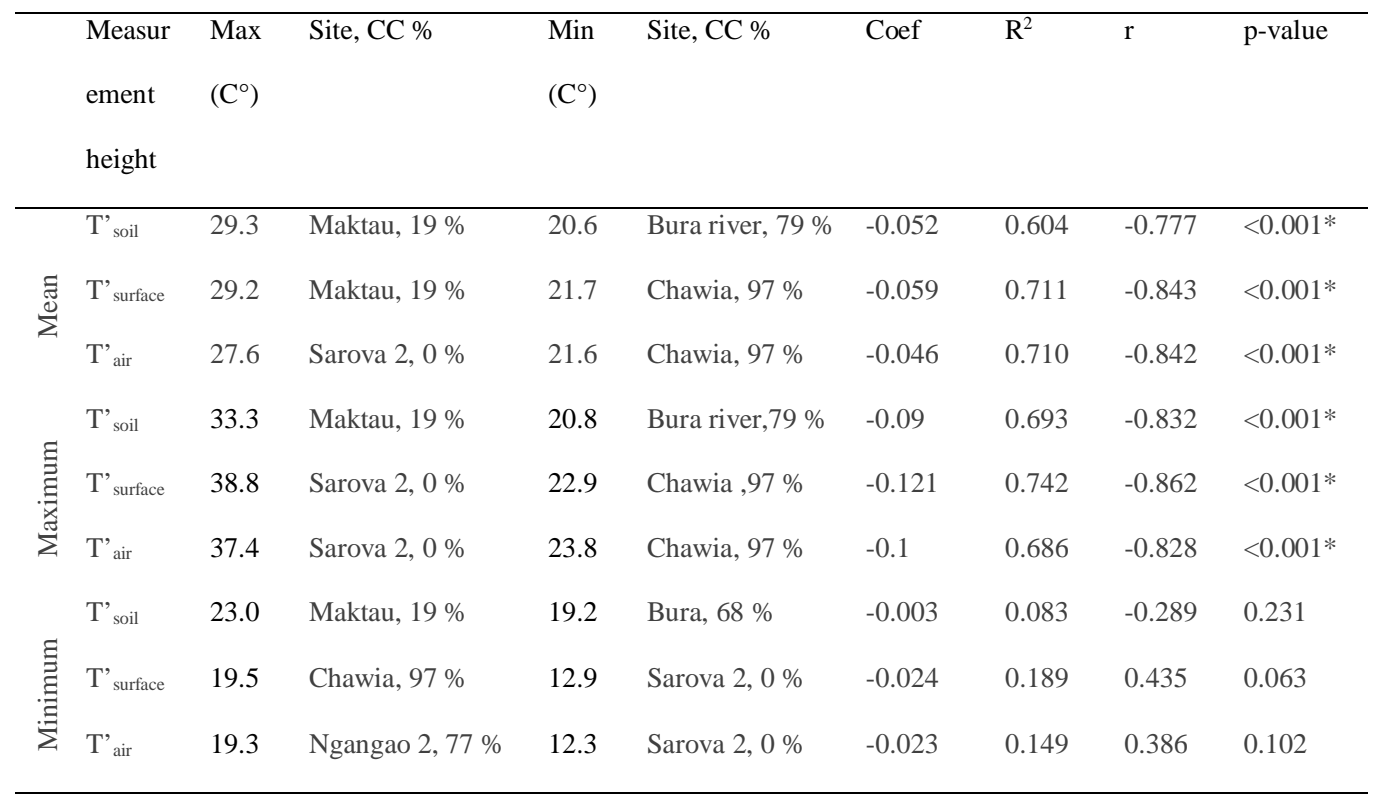

236 Table 3. Topographically corrected temperature (T') statistics for the soil, surface and air. Temperatures in the maximum

237 and minimum columns refer to the highest and lowest mean, maximum and minimum temperatures. Site refers to where

238 the highest and lowest temperatures were measured and their respective canopy cover $(\mathrm{CC})$ percentage. * indicates

239 statistical significance.

\section{$241 \quad 3.2$ Landsat 8 Land surface temperature}

\section{3.2.1 Land surface temperature compared with temperatures measured in the field}

243 LST and raw field temperatures (T) at the time of satellite overpass showed statistically significant correlation $(r=0.82$,

2440.79 and 0.84 at $\mathrm{T}_{\text {soil }}, \mathrm{T}_{\text {surface }}$ and $\mathrm{T}_{\text {air }}$, respectively) (Fig. 6). At 18 sites out of 19, LST was higher than $\mathrm{T}_{\text {soil, }}$ whereas 245 between LST and $\mathrm{T}_{\text {surface }}$ or $\mathrm{T}_{\text {air }}$ there was no consistent difference. Mean differences were $4.1{ }^{\circ} \mathrm{C}\left(\mathrm{T}_{\text {soil }}\right),-0.03{ }^{\circ} \mathrm{C}\left(\mathrm{T}_{\text {surface }}\right)$

246 and $0.57{ }^{\circ} \mathrm{C}\left(\mathrm{T}_{\text {air }}\right)$. The $\mathrm{T}_{\text {soil }}$ difference was statistically significant with $95 \%$ confidence, while $\mathrm{T}_{\text {surface }}$ and $\mathrm{T}_{\text {air }}$ not. 


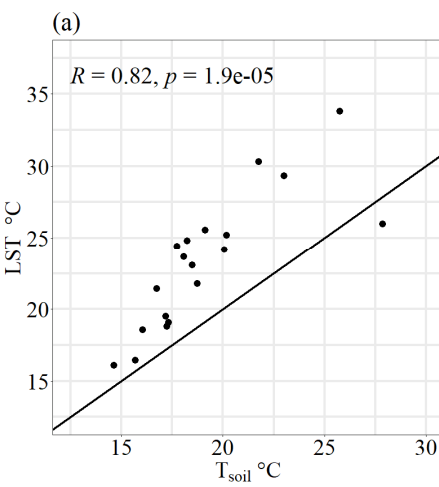

(b)

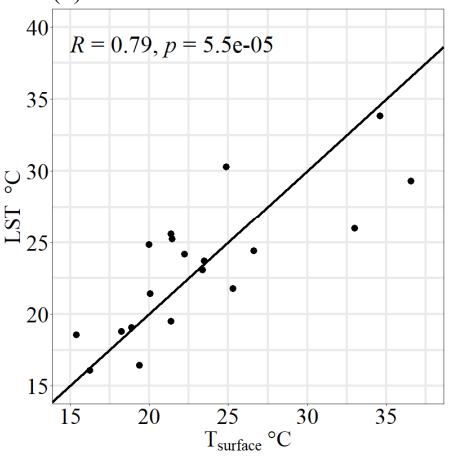

(c)

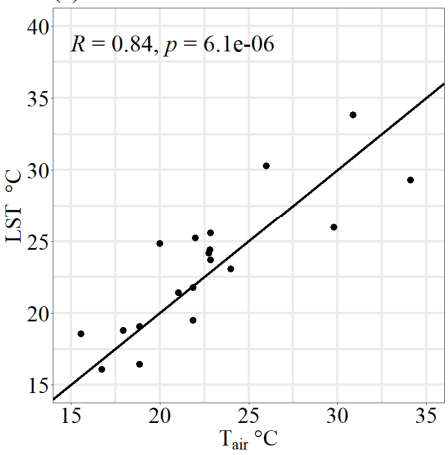

Figure 6: Landsat 8 land surface temperature (LST) compared with raw field temperatures (T) at the time of satellite overpass (10:30) on July 4, 2019. a) LST and soil temperature. b) LST and surface temperature. c) LST and air temperature.

\subsubsection{Impact of canopy cover on land surface temperature}

All the variables in Model 1 showed statistical significance $\left(R^{2}=0.74\right)$. Based on the regression analysis, generally the increase from zero \% CC to $100 \%$ CC decreased LST with $5{ }^{\circ} \mathrm{C}$ (Table 4). After the exclusion of other variables except CC, correlation between LST and CC was $-0.37(\mathrm{p}<0.001)$ and $R^{2}=0.14$. Topographic correction based on Model 1 improved the correlation coefficient to -0.42 and $R^{2}$ to 0.18 . In Model 2, three elevation zones were added to the model. This increased the $R^{2}$ to 0.77 , demonstrating a notable difference in the cooling effect of CC depending on elevation zone. At the elevations below $1000 \mathrm{~m}$, the cooling effect of $\mathrm{CC}$ when moving from zero $\% \mathrm{CC}$ to $100 \% \mathrm{CC}$ was $-6.6^{\circ} \mathrm{C}$, between $1000-1500 \mathrm{~m}$ the effect was $-3.2{ }^{\circ} \mathrm{C}$, and above $1500 \mathrm{~m}$ the effect was $-2.8^{\circ} \mathrm{C}$ (Table 4). Roughly, the cooling impact of $\mathrm{CC}$ was about a half in the hills compared to the effect in the lowlands. In Model 3, the interaction term of CC and elevation zones was replaced with interaction term of CC and the continuous variable elevation from the DEM. This produced $R^{2}=0.74$. The coefficient for the interaction term was 0.00005 , indicating that increase of $1000 \mathrm{~m}$ in elevation decreased the cooling effect of CC by $0.05{ }^{\circ} \mathrm{C}$ (Table 4). The model performed poorer compared to Model 2.

266 Model 4 was built up on Model 2 by adding interaction terms between aspect classes and CC (Table 4). According to the 267 results from Model 4, the magnitude of aspect's influence on the cooling effect of CC was mostly insignificantly small, 
269 performed best of the four $\left(R^{2}=0.77\right)$.

270 In summary, including either of the elevation factors (DEM or elevation zones) in the model showed that elevation

271 affected CC's cooling effect significantly, having two times higher impact in the lowlands compared to the hills. The

272 dependence of CC's impact on elevation is demonstrated in Fig. 7 using eight elevation classes. CC's coefficients

273 decreased with increasing elevation after $1000 \mathrm{~m}$, yet increased again between 1200-1400 m to roughly the same as in

274 the lowlands. The effect was the smallest in elevations above $1800 \mathrm{~m}$.

\begin{tabular}{|c|c|c|c|c|c|}
\hline Predictor & Model & Coef & Std. Error & T-Value & P-Value \\
\hline \multirow{4}{*}{ Constant } & 1 & 44.79 & 0.013 & 3324.0 & $<0.001 *$ \\
\hline & 2 & 44.24 & 0.019 & 2300.9 & $<0.001^{*}$ \\
\hline & 3 & 46.71 & 0.018 & 2580.3 & $<0.001^{*}$ \\
\hline & 4 & 44.38 & 0.021 & 2142.5 & $<0.001^{*}$ \\
\hline \multirow{4}{*}{ Elevation } & 1 & -0.013 & 0.000 & -1241.4 & $<0.001^{*}$ \\
\hline & 2 & -0.011 & 0.000 & -577.2 & $<0.001 *$ \\
\hline & 3 & -0.015 & 0.000 & -954.6 & $<0.001^{*}$ \\
\hline & 4 & -0.011 & 0.000 & -579.3 & $<0.001 *$ \\
\hline \multirow{4}{*}{ Slope } & 1 & -4.061 & 0.018 & -220.0 & $<0.001^{*}$ \\
\hline & 2 & -3.806 & 0.018 & -214.9 & $<0.001^{*}$ \\
\hline & 3 & -3.723 & 0.018 & -202.3 & $<0.001^{*}$ \\
\hline & 4 & -3.781 & 0.018 & -212.6 & $<0.001 *$ \\
\hline \multirow{4}{*}{ Canopy c } & 1 & -0.050 & 0.000 & -419.0 & $<0.001^{*}$ \\
\hline & 2 & -0.068 & 0.000 & -449.1 & $<0.001^{*}$ \\
\hline & 3 & -0.109 & 0.000 & -274.7 & $<0.001^{*}$ \\
\hline & 4 & -0.073 & 0.000 & -208.0 & $<0.001^{*}$ \\
\hline \multirow{4}{*}{$\mathrm{NE}$} & 1 & 0.177 & 0.011 & 16.0 & $<0.001^{*}$ \\
\hline & 2 & 0.084 & 0.010 & 8.1 & $<0.001^{*}$ \\
\hline & 3 & 0.157 & 0.011 & 14.3 & $<0.001^{*}$ \\
\hline & 4 & -0.215 & -0.015 & -14.0 & $<0.001 *$ \\
\hline
\end{tabular}


https://doi.org/10.5194/bg-2021-261

Preprint. Discussion started: 21 October 2021

(c) Author(s) 2021. CC BY 4.0 License.

\begin{tabular}{|c|c|c|c|c|c|}
\hline \multirow{4}{*}{$\mathrm{E}$} & 1 & -0.030 & 0.010 & -29.0 & $<0.001 *$ \\
\hline & 2 & -0.428 & 0.010 & -44.6 & $<0.001 *$ \\
\hline & 3 & -0.352 & 0.010 & -34.7 & $<0.001 *$ \\
\hline & 4 & -0.766 & 0.014 & -55.2 & $<0.001 *$ \\
\hline \multirow{4}{*}{ SE } & 1 & -1.447 & 0.010 & -140.0 & $<0.001 *$ \\
\hline & 2 & -1.509 & 0.010 & -155.6 & $<0.001 *$ \\
\hline & 3 & -1.529 & 0.010 & -149.3 & $<0.001 *$ \\
\hline & 4 & -1.733 & 0.014 & -127.3 & $<0.001 *$ \\
\hline \multirow{4}{*}{ S } & 1 & -2.095 & 0.011 & -189.4 & $<0.001 *$ \\
\hline & 2 & -2.132 & 0.010 & -205.2 & $<0.001 *$ \\
\hline & 3 & -2.186 & 0.011 & -199.4 & $<0.001 *$ \\
\hline & 4 & -2.166 & 0.014 & -153.3 & $<0.001 *$ \\
\hline \multirow{4}{*}{ SW } & 1 & \begin{tabular}{|l|}
-2.441 \\
\end{tabular} & 0.011 & -230.0 & $<0.001 *$ \\
\hline & 2 & -2.554 & 0.010 & -256.0 & $<0.001 *$ \\
\hline & 3 & -2.527 & 0.011 & -240.1 & $<0.001 *$ \\
\hline & 4 & -2.538 & 0.014 & -185.9 & $<0.001 *$ \\
\hline \multirow{4}{*}{ W } & 1 & -2.293 & 0.010 & -219.5 & $<0.001 *$ \\
\hline & 2 & -2.254 & 0.010 & -229.9 & $<0.001 *$ \\
\hline & 3 & -2.332 & 0.010 & -225.5 & $<0.001 *$ \\
\hline & 4 & -2.195 & 0.014 & -159.0 & $<0.001 *$ \\
\hline \multirow{4}{*}{ NW } & 1 & -1.380 & 0.011 & -126.8 & $<0.001 *$ \\
\hline & 2 & -1.205 & 0.010 & -117.9 & $<0.001 *$ \\
\hline & 3 & -1.379 & 0.012 & -127.9 & $<0.001 *$ \\
\hline & 4 & -1.196 & 0.015 & -81.9 & $<0.001 *$ \\
\hline \multirow{4}{*}{$1000-1500 \mathrm{~m}$} & 1 & & & & \\
\hline & 2 & -2.667 & 0.008 & -346.9 & $<0.001 *$ \\
\hline & 3 & & & & . \\
\hline & 4 & -2.678 & 0.008 & -348.5 & $<0.001 *$ \\
\hline$>1500 \mathrm{~m}$ & 1 & . & . & . & . \\
\hline
\end{tabular}


https://doi.org/10.5194/bg-2021-261

Preprint. Discussion started: 21 October 2021

(c) Author(s) 2021. CC BY 4.0 License.

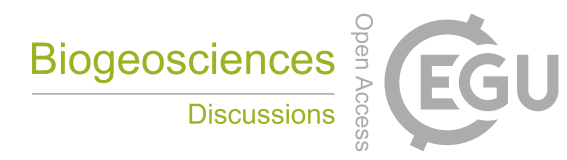

\begin{tabular}{|c|c|c|c|c|c|}
\hline & 2 & -2.030 & 0.018 & -111.2 & $<0.001 *$ \\
\hline & 3 & . & . & . & . \\
\hline & 4 & -2.006 & 0.018 & -110.0 & $<0.001 *$ \\
\hline & 1 & & . & . & . \\
\hline Canopy cover: $1000-$ & 2 & 0.031 & 0.000 & 149.7 & $<0.001 *$ \\
\hline \multirow[t]{3}{*}{$1500 \mathrm{~m}$} & 3 & . & . & . & . \\
\hline & 4 & 0.032 & 0.000 & 153.5 & $<0.001 *$ \\
\hline & 1 & . & . & . & . \\
\hline Canopy cover: & 2 & 0.028 & 0.000 & 120.7 & $<0.001 *$ \\
\hline \multirow[t]{3}{*}{$>1500 \mathrm{~m}$} & 3 & . & . & . & . \\
\hline & 4 & 0.038 & 0.000 & 121.6 & $<0.001 *$ \\
\hline & 1 & . & . & . & . \\
\hline Elevation: canopy & 2 & . & . & . & . \\
\hline \multirow[t]{2}{*}{ cover } & 3 & 0.00005 & 0.000 & 156.3 & $<0.001 *$ \\
\hline & 4 & . & . & . & . \\
\hline \multirow{4}{*}{ Canopy cover: NE } & 1 & . & . & . & . \\
\hline & 2 & . & . & . & . \\
\hline & 3 & . & . & . & . \\
\hline & 4 & 0.011 & 0.000 & 25.6 & $<0.001 *$ \\
\hline \multirow{4}{*}{ Canopy cover: E } & 1 & . & . & . & . \\
\hline & 2 & . & . & . & . \\
\hline & 3 & . & . & . & . \\
\hline & 4 & 0.013 & 0.000 & 32.6 & $<0.001 *$ \\
\hline \multirow{4}{*}{ Canopy cover: SE } & 1 & . & . & . & . \\
\hline & 2 & . & . & . & . \\
\hline & 3 & . & . & . & . \\
\hline & 4 & 0.010 & 0.000 & 24.0 & $<0.001 *$ \\
\hline
\end{tabular}

Canopy cover: S 
https://doi.org/10.5194/bg-2021-261

Preprint. Discussion started: 21 October 2021

(c) Author(s) 2021. CC BY 4.0 License.

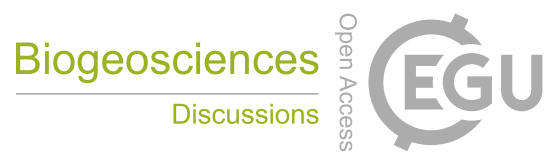

\begin{tabular}{|c|c|c|c|c|c|}
\hline & 3 & . & . & . & . \\
\hline & 4 & -0.000 & 0.000 & -0.2 & 0.8 \\
\hline \multirow{4}{*}{ Canopy cover: SW } & 1 & . & . & . & \\
\hline & 2 & . & . & . & . \\
\hline & 3 & . & . & . & \\
\hline & 4 & -0.003 & 0.000 & -8.0 & $<0.001^{*}$ \\
\hline \multirow{4}{*}{ Canopy cover: W } & 1 & 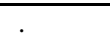 & 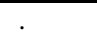 & 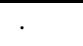 & . \\
\hline & 2 & . & . & . & \\
\hline & 3 & & & . & . \\
\hline & 4 & -0.003 & 0.000 & -7.8 & $<0.001 *$ \\
\hline \multirow{4}{*}{ Canopy cover: NW } & 1 & . & . & . & \\
\hline & 2 & . & & . & . \\
\hline & 3 & . & . & . & . \\
\hline & 4 & -0.000 & 0.000 & -1.2 & 0.25 \\
\hline
\end{tabular}

276 Table 4: Summary of regression coefficients in the analysis of land surface temperature (LST) from the four models

277 tested. * indicates statistical significance. 
(a) $<800 \mathrm{~m}$

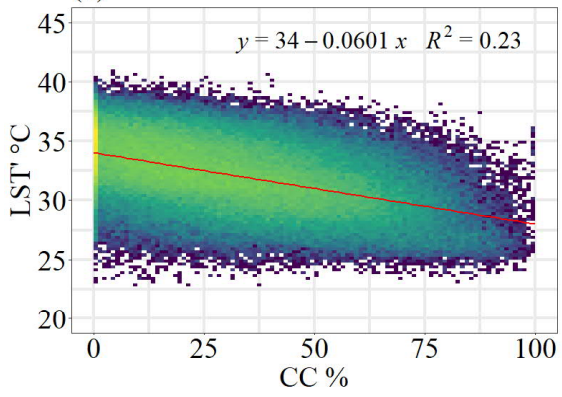

(c) $1000-1200 \mathrm{~m}$

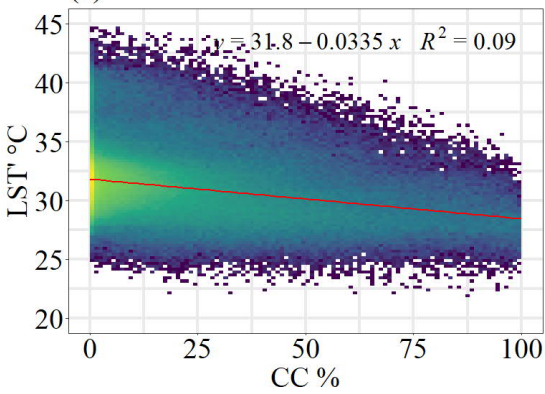

(e) $1400-1600 \mathrm{~m}$

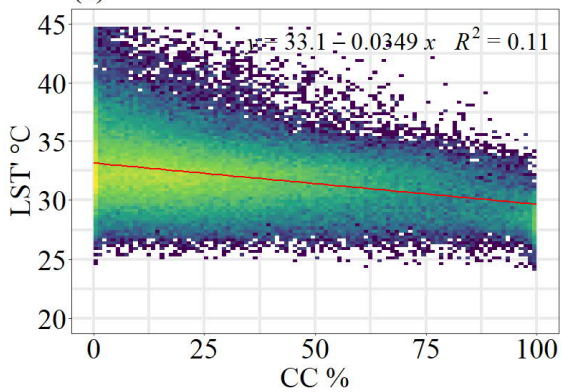

(g) 1800-2000 m

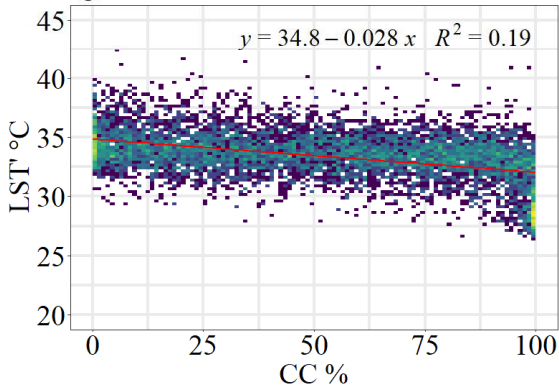

(b) $800-1000 \mathrm{~m}$

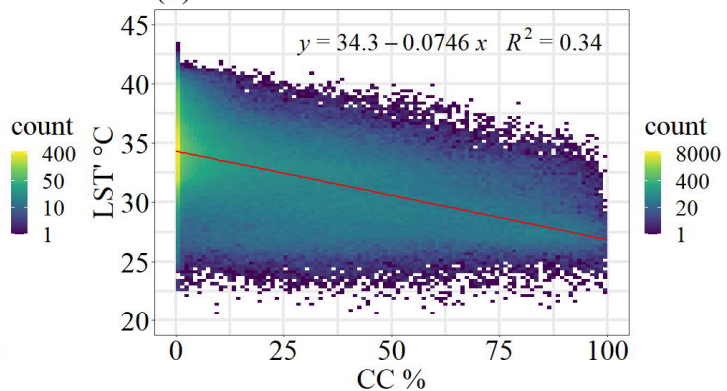

(d) $1200-1400 \mathrm{~m}$

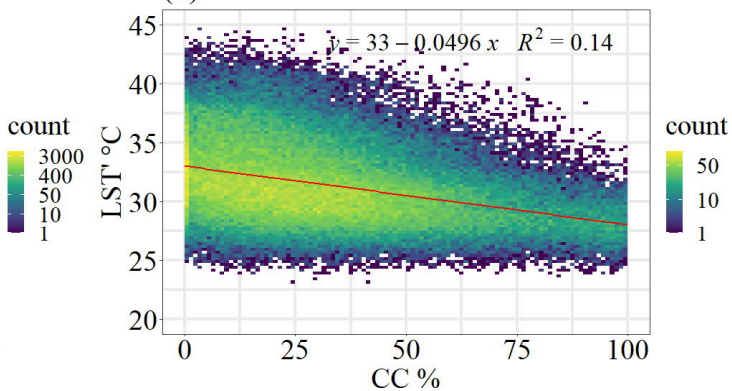

(f) $1600-1800 \mathrm{~m}$

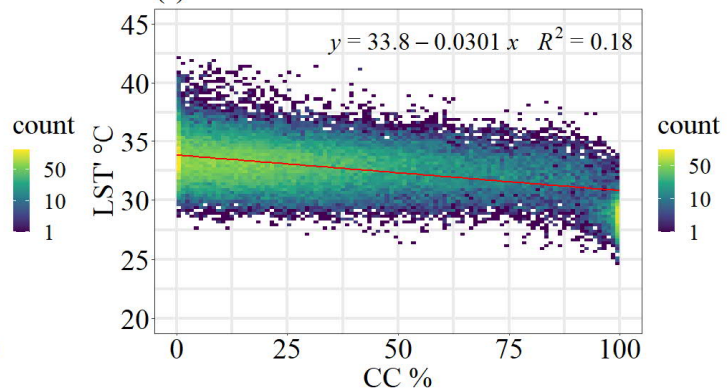

(h) $>2000 \mathrm{~m}$

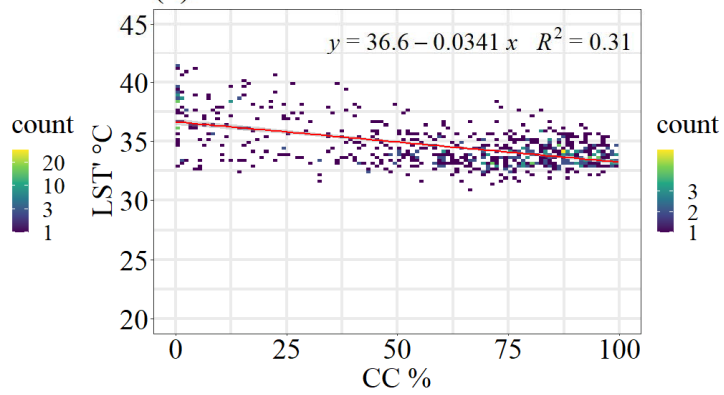

Figure 7: Density plots of topographically corrected land surface temperature (LST') and canopy cover (CC) percentage 
https://doi.org/10.5194/bg-2021-261

Preprint. Discussion started: 21 October 2021

(c) Author(s) 2021. CC BY 4.0 License.

\section{Discussion}

284 High CC decreased near-ground mean temperatures on average by $5.7{ }^{\circ} \mathrm{C}$ compared to open land, depending on

285 measurement height. The difference was even greater in temperature maxima, which has been reported to be the case also

286 by De Frenne et al. (2019) and Belsky et al. (1989). Temperature and CC had a linear relationship, pointing out that closed

287 CC was not needed for a sensible cooling effect. $\mathrm{T}_{\text {surface }}$ was affected the most by CC. Despite the measurement height of

$288 \mathrm{~T}_{\text {surface }}$ being only $13 \mathrm{~cm}$ below $\mathrm{T}_{\text {air }}$, the effect of $\mathrm{CC}$ was notably weaker in $\mathrm{T}_{\text {air }}$, which is in line with previous studies.

289 For example, Luyssaert et al. (2014) report that the temperature of the planetary boundary was less affected than LST by

290 the removal of forest cover, while in De Frenne et al. (2019) temperature offset between forest and open land was the

291 greatest close to the ground. In Belsky et al. (1989), soil temperature was the least affected by CC.

292 The prevalent temperatures affected the magnitude of the cooling: in elevations above $1000 \mathrm{~m}$, the cooling effect

293 decreased remarkably by approximately $50 \%$ compared to the lowlands. Moreover, based on the temporal data from the

294 microclimate sensors, during the cooler days of overcast conditions, CC's cooling effect was smaller. Additionally, the

295 temperature differences between low and high CC sites were smaller during these days. One likely reason behind the

296 phenomenon is that plant evapotranspiration rates are relative to the solar radiation and ambient temperatures (Allen et

297 al. 1998). It can be concluded that trees' importance in controlling temperatures increases in hotter environments. The

298 discovery is meaningful, since agricultural expansion on the cost of woody vegetation cover in the area is predicted to

299 take place predominantly in the lowlands (Erdogan et al. 2011; Maeda et al., 2010), where the temperatures are very high.

300 Increasing tree cover on farmlands could thus be of considerable benefit in decreasing local temperatures.

301 The impact of CC on temperature is also most likely different on different days and different times of the year. For

302 instance, Maeda and Hurskainen (2014) found that land cover's influence on LST in Mount Kilimanjaro varied seasonally

303 and diurnally, and the effect was dependent on elevation. Our LST estimation using the satellite image was only a snapshot

304 for July 4, 2019, from a sunny almost cloud-free day, and does not represent the year-round situation experiencing two

305 rainy seasons, which are cloudy. In the hills, cloudy and misty conditions are experienced throughout the year (Helle,

306 2016; Räsänen et al., 2018). A time series comparing the cooling effect of CC over seasons and several years is an

307 interesting future research topic, as the TOMST sensors remained in the 19 field plots. Interesting would also be to model

308 the sunshine hours every day in the locations of the TOMST sensors using the hemispherical photography, in order to

309 assess how many hours of the day the tree cover causes shadows on the sensor. 
https://doi.org/10.5194/bg-2021-261

Preprint. Discussion started: 21 October 2021

(c) Author(s) 2021. CC BY 4.0 License.

310 The thermal environments of forests are controlled by canopies to a high extent, which was reaffirmed in this study.

311 Therefore, CC can mitigate large-scale macroclimate warming (De Frenne et al., 2019). An increase of $2{ }^{\circ} \mathrm{C}$ of the global

312

313

314

315

316

317

318

319

320

321

322

323

324

325

326

327

328

329

330

331

332

333

334

335

336

337

338

339 temperature as a consequence of enhanced greenhouse effect can have detrimental impacts on the most vulnerable ecosystems (IPCC, 2018). Since the time span of local changes in temperatures due to LULCC is much shorter than in the global climate change, the regional and local consequences can be of even higher extent (Chen et al., 1999). Due to the debts of species' adaptation capabilities to climate warming (Zellweger et al., 2020), changes in the microclimate temperatures may be fatal for flora and fauna occupying narrow thermal niches. This may further impact biodiversity and consequently the crucial ecosystem services provided by forests that take place close to ground surface (Chen, et al. 1999; Zellweger et al., 2020).

Forest fragmentation decreases the ability of tropical forest to mitigate climate change (Ewers and Banks-Leite, 2013), but on regional scale even small forests have an impact on LST (Mildrexler et al., 2011). Our results revealed that trees on farms had the same effect on local temperatures as forests despite the smaller scale, and could hence help in conserving the biodiversity. For instance, Mendenhall et al. (2016) found that in Costa Rica farm trees increased the number of tree and plant species. Most of the CC in Taita Hills comprises of TOF, occurring on farms and human settlement. Sites with agroforestry trees and moderate $\mathrm{CC}$ were already experiencing both lower mean and maximum temperatures than the open sites.

In Taita Hills, Pellikka et al. (2018) reported an addition in carbon stocks since 2003. The Agriculture (Farm Forestry) Rules of 2009 requires that at least $10 \%$ forest cover should be left or planted on farms. Based on our results, this $10 \%$ CC makes a significant difference in temperatures. Soil and air temperatures have an impact to crop productivity, and furthermore, the fog deposit captured by trees brings more water to plants. In general, increasing temperatures make plant growth more efficient, but this is the case only as long as the increase occurs within the thermal limits of the plant's tolerance (Muimba-Kankolongo, 2018). As extreme heat and precipitation events are becoming more common with climate change (MoALF, 2016; IPCC, 2018), the negative effects of warming will become notable in sub-Saharan Africa. This further threatens the food security, and especially the most common crop, maize, which is one of the most vulnerable crops in terms of climate change in Africa (Cairns et al., 2013; Adhikari et al., 2015). Forests of Taita Hills contribute to the food security by capturing atmospheric moisture as fog deposit and storing the water providing water for farms in the foothills and lowlands (Pellikka et al., 2013; Helle, 2016).

The pressure on tropical forests in sub-Saharan Africa is caused by many reasons, fuelwood collection being significant (Abdelgalil, 2004), which could be mitigated by increasing the tree cover on farms (Unruh et al., 1993). The results of this study further encourage to increase tree cover in particular in the lowland farms as a strong potential way to fight the 
https://doi.org/10.5194/bg-2021-261

Preprint. Discussion started: 21 October 2021

(c) Author(s) 2021. CC BY 4.0 License.

340 negative effects of climate change. Nevertheless, water is scarce especially in the lowland areas, and trees' vast need for

341 water must be taken into account. The phenomenon is paradoxical, since trees improve the water cycle, in general, but

342 are consumes high amounts of water (Ong et al., 2006). In areas with water scarcity, the competition of water resources

343 with crops, animals and people may be a limiting factor in the adoption of agroforestry practices. One solution in the hot

344 lowlands is dew collection, but it would require a tree cover or other surfaces to capture the humidity. In Tuure et al.

345 (2019), artificial surfaces produced at best 0.1 liter per day and 25 liters in a year water from morning dew.

346 This study was limited to a short time span and a small sample size in microclimate study sites, which makes it susceptible

347 for uncertainties associated with temporal and spatial variability. Topographic correction was applied on the microclimate

348 data and was calculated based on elevation only. The small amount of observations did not allow for calculation the

349 impact of the aspect, which is expected to exist based on the LST analysis. Due to the topographic manipulation of the

350 temperatures, they did not represent the true values recorded, but made the temperatures comparable by CC. In terms of

351 LST, as has been documented in several studies, spaceborne TIR remains an uncertain method for accurate LST retrieval

352 (Simó et al., 2018; Li et al., 2013). After all, LST is an indirect measurement and the results of complicated mathematical

353 processing requiring knowledge of several components, where error in any of them causes inaccuracies in LST (Simó et

354 al., 2018). Estimation of land surface emissivity is determinant in the correct LST retrieval, yet highly difficult to measure

355 and prone to error. Moreover, in dense canopies the signal constitutes mostly of the upper canopy and does not necessarily

356 capture the temperatures on the forest floor, which may not make LST representative of understory conditions (Bense et

357 al., 2016; Zellweger et al., 2019). Landsat 8 TIRS band 11 was not used in this study due to the stray light problem,

358 which exposes even higher possibility of inaccuracy with LST. However, Wang et al. (2019) conclude that the SC is a

359 valid method for Landsat 8 processing and produces results on accuracy high enough for most purposes.

Despite its limitations, this study provided information about a topic of which importance has only recently been recognized (De Frenne et al., 2013; Jucker et al., 2018; Zellweger et al., 2020). Research and modelling of climate change implications on microclimate cannot rely on observations from weather stations with low spatial resolution, but need data that represent the microclimatic conditions relevant for most ecosystem functions. Previous research about vegetation and

364 LST have been often conducted at much lower spatial resolutions and applied less accurate topographic correction (Li et

365 al., 2015). Furthermore, the effect of trees on climate is usually studied solely based on comparison between forest and

366 open land (De Frenne et al., 2019), neglecting the intermediate canopies and their significance, despite of the fact that

367 human activity focuses mostly in areas with TOF. We used microclimate data covering a CC gradient and satellite-derived

368 LST data combined with a DEM of $30 \mathrm{~m}$ acquired with ALS over the versatile and precise study area. While establishing 

proxy for assessing the impacts of $\mathrm{CC}$ on microclimate.

371 Future research should further investigate the contribution of varied factors to microclimate. For example, since all trees

372 are not of equal benefits in agroforestry, more studies could be targeted to the comparison of different agroforestry

373 species' cooling potential as well as the potential of plantation forests. Including soil moisture, air temperature and comprehensive field plot networks under different canopy structures in the future analyses should broaden the knowledge about trees' role in mitigating and adapting to climate change.

\section{Conclusions}

378 Our results demonstrate a consistent but heterogeneous influence of canopy cover on the microclimate of highly diverse

379 tropical ecosystems. Daytime temperatures correlated inversely with canopy cover, the effect being strongest on surface

380 temperatures. During the hottest days, the difference between sites of high and low canopy cover became most notable.

381 The cooling effect did not exist only with high canopy cover, but even intermediate canopy cover and trees outside forest

382 buffered the hottest temperatures. Our results thus provide robust evidence that any efforts in the direction of preserving,

383 restoring or increasing vegetation cover can have a substantial impact in creating more stable and cooler microclimates.

384 Satellite based LST was a suitable proxy for assessing microclimatic variables surface- and near-ground temperatures,

385 particularly in heterogeneous regions, where the network of field measurements cannot cover the spatial microclimate variability.

387 This study provided valuable information about the potential of trees in climate change adaptation and mitigation in

388 tropical environments. As the effect of canopy cover on microclimate increased at lower elevations and during hot days, our results indicate that warmer and drier regions are likely to benefit the most from trees. 
https://doi.org/10.5194/bg-2021-261

Preprint. Discussion started: 21 October 2021

(c) Author(s) 2021. CC BY 4.0 License.

391 We took hemispherical photographs at every microclimate sensor site. The camera in use was Nikon D5000 DSLR and the lens Sigma $4.5 \mathrm{~mm}$ F2.8 EX DC HSM Circular Fisheye. The camera was attached to a tripod during the taking of photographs. We took photographs at two different heights: the lowest possible tripod adjustment to be as close to the actual sensor level as possible, which was around $60 \mathrm{~cm}$, and at eye-level around $130 \mathrm{~cm}$. We took photographs at eyelevel also to every intercardinal direction 15 meters away from the sensor. The camera was adjusted looking upward with the top of the camera pointing north. Two images at every height and direction were taken with different settings: first image on Program mode with automatic aperture and shutter speed, and the second on Manual mode with the rest of the settings staying the same as in picture one, except shutter speed was reduced to half of the first mage. The ISO value was set as constant 500. The purpose of the smaller shutter speed was to reduce the impact of light conditions that were not optimal, meaning direct sunlight that causes overexposure of images which in turn makes them difficult to analyze. Optimally, the photographs should be taken under constant cloud cover or at the dawn or dusk (Pellikka et al., 2000), however due to the timetable, waiting for better light conditions at some sites was not possible, thus some images were overexposed.

We analyzed the hemispherical photographs in the software Hemisfer (WSL; version 2.2) (Schleppi et al., 2007; Thimonier et al., 2010). From the two images, we used the less exposed one in the analysis. For the calculation of canopy cover, we used the images taken from eye-level, because they were more comparable to the ALS-based canopy cover, and the photographs in cardinal directions were all taken at eye-level. We classified the image pixels to sky and canopy by determining a threshold value to separate dark and light pixels in the image. For most images, we used the automatic threshold method by Nobis and Hunziker (2005). In the case of some images, the algorithm clearly produced errors due to overexposure and direct sunlight, therefore the algorithm by Ridler and Calvart (1978) was applied, or a manual threshold was determined. We used only the blue band in the analysis, apart from photographs where the classification was failing and using all the bands produced the best result (Heiskanen et al., 2015a). The gamma correction was $\gamma=2.2$. Only the zenith angle range of $0-15^{\circ}$ was analyzed, because errors in canopy cover accuracy increase with larger angles (Paletto and Tosi, 2009). We computed canopy cover by calculating an average of 1-gap fraction of the five measurements, and this gave a plot-wise canopy cover (Heiskanen, et al., 2015b). Finally, we compared the canopy cover retrieved from hemispherical photography and ALS using Pearson's correlation and a Student's t-test. 
https://doi.org/10.5194/bg-2021-261

Preprint. Discussion started: 21 October 2021

(c) Author(s) 2021. CC BY 4.0 License.

419 The data and scripts presented in this study are available on request from the author (I.A.).

420 Author contribution

421 Conceptualization, I.A., E.M., J.H. and P.P.; data curation, I.A.; formal analysis, I.A., E.A.; funding acquisition, P.P.;

422 investigation, I.A., methodology, I.A, E.M., J.H., E.A. and P.P.; project administration, E.M. and P.P.; resources,

423 software, I.A.; supervision, E.M, J.H. and P.P.; validation, I.A., visualization, I.A., writing—original draft preparation,

424 I.A.; writing — review and editing, IA., E.M., J.H. and P.P. All authors have read and agreed to the published version of

425 the manuscript.

\section{Declaration of Competing Interest}

427

The authors declare that they have no conflicts of interest.

\section{Funding}

This study was conducted as part of Smartland project (Environmental sensing of ecosystem services for developing a climate-smart landscape framework to improve food security in East Africa, decision no. 31864) funded by Academy of Finland, and ESSA project (Earth observation and environmental sensing for climate-smart sustainable agropastoral ecosystem transformation in East Africa) funded by European Commission DG International Partnerships DeSIRA programme (FOOD/2020/418-132). Eduardo Maeda was funded by the Academy of Finland (decision numbers 318252 and 319905).

\section{Acknowledgements}

We would like to acknowledge Agnes Mwangombe, Ali Ndizi, Mrs. Mwamburis, Mrs. Nyatta, Cathrine Mwakesi, Simon, Moses Onyimbo and Dalmas moka secondary school, Jason Collette and Teita Sisal Estate, St. Mary's Teachers’ Training College, and Taita Taveta University Ngerenyi campus for allowing us to conduct this research on their properties. We also thank Taita Research Station of the University of Helsinki for logistical support during the field wok campaign. Special thanks to Mwadime Mjomba for assistance during the field work. We acknowledge Matti Räsänen for the provision of weather station data and Hari Adhikari for the canopy cover data. 
https://doi.org/10.5194/bg-2021-261

Preprint. Discussion started: 21 October 2021

(c) Author(s) 2021. CC BY 4.0 License.

Abdelgalil, E. A.: Deforestation in the drylands of Africa: Quantitative modelling approach, Environment, Development and Sustainability, 6, 415-427, http://dx.doi.org/10.1007/s10668-005-0787-1, 2004.

Abera, T. A., Heiskanen, J., Pellikka, P. K., Adhikari, H., and Maeda, E. E.: Climatic impacts of bushland to cropland conversion in Eastern Africa, Sci. Total. Environ., 717, https://doi.org/10.1016/j.scitotenv.2020.137255, 2020. https://doi.org/10.3390/rs9080827, 2017. major crops, Food and Energy Security, 4, 110-132. http://dx.doi.org./10.1002/fes3.61, 2015. Agriculture (Farm Forestry) Rules, 2009 (Cap. 318) (KEN). Allen, R. G., Pereira, L. S., Raes, D., and Smith, M.: Crop evapotranspiration - Guidelines for computing crop water requirements, Food and Agriculture Organization of the United Nations, Rome, Italy, 1998 Biomass Distribution in a Multi-Use Savannah Landscape in Southeastern Kenya: Impact of Land Use and Fences, Land, 9, 381, https://doi.org/10.3390/land9100381, 2020. Dioxide Uptake Distribution and Covariation with Climate, Science, 329, 834-838, https://doi.org/10.1126/science.1184984, 2010. Belsky, A. J., Amundson, R. G., Duxbury, J. M., Riha, S. J., Ali, A. R., and Mwonga, S. M.: The Effects of Trees on Their Physical, Chemical and Biological Environments in a Semi-Arid Savanna in Kenya, J. Appl. Ecol., 26, 10051024. https://doi.org/10.2307/2403708, 1989. Bense, V. F., Read, T., and Verhoef, A.: Using distributed temperature sensing to monitor field scale dynamics of ground surface temperature and related substrate heat flux, Agr. Forest. Meteorol., 220, 207-215. https://doi.org/10.1016/j.agrformet.2016.01.138, 2016.

468 Cairns, J. E., Hellin, J., Sonder, K., Araus, J. L., MacRoberts, J. F., Thierfelder, C., and Prasanna, B. M.: Adapting 469 maize production to climate change in sub-Saharan Africa, Food Secur., 5, 345-360, https://doi.org/10.1007/s12571470 013-0256-x, 2013. 
https://doi.org/10.5194/bg-2021-261

Preprint. Discussion started: 21 October 2021

(c) Author(s) 2021. CC BY 4.0 License.

471 Chen, J., Saunders, S. C., Crow, T. R., and Naiman, R. J.: Microclimate in forest ecosystem and landscape ecology,

472 Bioscience, 49, 288-297, http://dx.doi.org/10.2307/1313612, 1999.

473 Das, A., Nagendra, H., Anand, M., and Bunyan, M.: Topographic and Bioclimatic Determinants of the Occurrence of

474 Forest and Grassland in Tropical Montane Forest-Grassland Mosaics of the Western Ghats, India, PLoS One, 10,

475 e0130566, http://dx.doi.org/10.1371/journal.pone.0130566, 2015.

476 De Frenne, P., Rodríguez-Sánchez, F., Coomes, D. A., Baeten, L., Verstraeten, G., Vellend, M., ... Verheyen, K.:

477 Microclimate moderates plant responses to macroclimate warming, P. Natl. Acad. Sci. USA., 110, 18561-18565,

478 https://doi.org./10.1073/pnas.1311190110, 2013.

479 De Frenne, P., Zellweger, F., Rodríguez-Sánchez, F., Scheffers, B. R., Hylander, K., Luoto, M., . . . Lenoir, J.: Global

480 buffering of temperatures under forest canopies, Nat. Ecol. Evol., 3, 744-749, http://dx.doi.org/10.1038/s41559-019-

$481 \quad 0842-1,2019$.

482 Ellison, D., Morris, C. E., Locatelli, B., Sheil, D., Cohen, J., Murdiyarso, D., . . . Sullivan, C. A.: Trees, forests and

483 water: Cool insights for a hot world, Global Environ. Chang., 43, 51-61,

484 https://doi.org/10.1016/j.gloenvcha.2017.01.002, 2017.

485 Erdogan, H. E., Pellikka, P. K., and Clark, B.: Modelling the impact of land-cover change on potential soil loss in the

486 Taita Hills, Kenya, between 1987 and 2003 using remote-sensing and geospatial data, Int. J. Remote Sens., 32, 5919-

487 5945, https://doi-org.libproxy.helsinki.fi/10.1080/01431161.2010.499379, 2011.

488 Ewers, R. M., and Banks-Leite, C.: Fragmentation Impairs the Microclimate Buffering Effect of Tropical Forests, PLoS One, 8, e58093, https://doi.org/10.1371/journal.pone.0058093, 2013.

490

FAO: Global Forest Resources Assessment 2000 (FRA 2000). Food and Agriculture Organization of the United

491 Nations, Rome, Italy, 2000.

FAO: Forest Resources Assessment. Terms and definitions. Food and Agriculture Organization of the United Nations,

Rome, Italy, 2015.

494

FAO: Global forest resources assessment 2015. How are the world's forests changing? (2 ed.), Food and Agriculture 
https://doi.org/10.5194/bg-2021-261

Preprint. Discussion started: 21 October 2021

(c) Author(s) 2021. CC BY 4.0 License.

496 Griffin, A. M., Popescu, S. C., and Zhao, K.: Using LIDAR and Normalized Difference Vegetation Index to remotely

497 determine LAI and percent canopy cover, in: SilviLaser, Edinburgh, United Kingdom, 17-19 September, 446-455,

4982008.

499 He, J., Zhao, W., Li, A., Wen, F., and Yu, D.: The impact of the terrain effect on land surface temperature variation

500 based on Landsat-8 observations in mountainous areas, Int. J. Remote Sens., 40, 1808-1827,

501 https://doi,org/10.1080/01431161.2018.1466082, 2019.

502 Heiskanen, J., Korhonen, L., Hietanen, J., and Pellikka, P. K.: Use of airborne lidar for estimating canopy gap fraction

503 and leaf area index of tropical montane forests, Int. J. Remote Sens., 36, 2569-2583,

504 https://doi.org/10.1080/01431161.2015.1041177, 2015a.

505 Heiskanen, J., Korhonen, L., Hietanen, J., Heikinheimo, V., Schäfer, E., and Pellikka, P. K. E.: Comparison of field and

506 airborne laser scanning based crown cover estimates across land cover types in Kenya, Int. Arch. Photogramm. Remote

507 Sens. Spatial Inf. Sci., XL-7/W3, 409-415, https://doi.org/10.5194/isprsarchives-XL-7-W3-409-2015, 2015 b.

508 Helle, J.: Lentolaserkeilaus ja hemisfäärikuvaus metsikkösadannan tutkimisessa Taitavuorilla Keniassa, B.Sc. thesis,

509 University of Helsinki, 2016.

510 IPCC: Global Warming of $1.5^{\circ} \mathrm{C}$. An IPCC Special Report on the impacts of global warming of $1.5^{\circ} \mathrm{C}$ above pre-

511 industrial levels and related global greenhouse gas emission pathways, in the context of strengthening the global

512 response to the threat of climate change, sustainable development, and efforts to eradicate poverty, Intergovernmental

513 Panel on Climate Change, 2018.

514 Jiménez-Muñoz, J. C., and Sobrino, J. A.: A generalized single-channel method for retrieving land surface temperature

515 from remote sensing data, J. Geophys. Res., 108, 4688, https://doi.org/10.1029/2003JD003480, 2003.

516 Jiménez-Muñoz, J. C., Sobrino, J. A., Skoković, D., Mattra, C., and Cristóbal, J.: Land Surface Temperature Retrieval

517 Methods from Landsat-8 Thermal Infrared Sensor Data. IEEE Geosci. Remote S., 11, 1840-1843,

518 https://doi.org/10.1109/LGRS.2014.2312032, 2014.

519 Jin, M., and Dickinson, R. E.: Land surface skin temperature climatology: benefitting from the strengths of satellite

520 observations, Environ. Res. Lett., 5, https://doi.org/10.1088/1748-9326/5/4/044004, 2010.

521 Jucker, T., Hardwick, S. R., Both, S., Elias, D. D., Ewers, R. M., Milodowski, D. T. . . Coomes, D. A.: Canopy

522 structure and topography jointly constrain the microclimate of human-modified tropical landscapes, Glob. Change Biol.,

$52324,5243-5258$, https://doi.org/10.1111/gcb.14415, 2018. 
https://doi.org/10.5194/bg-2021-261

Preprint. Discussion started: 21 October 2021

(c) Author(s) 2021. CC BY 4.0 License.

524 Kim, J.-P.: Variation in the accuracy of thermal remote sensing, Int. J. Remote Sens., 34, 729-750,

525

526

527

528

529

530

531

532

533

534

535

536

537

538

539

540

541

542 https://doi.org/10.1080/01431161.2012.713143, 2013.

Korhonen, L., Korhonen, K. T., Rautiainen, M., and Stenberg, P.: Estimation of Forest Canopy Cover: A Comparison of Field Measurement Techniques, Silva Fenn., 40, 577-588, https://doi.org/10.14214/sf.315, 2006.

Li, Y., Zhao, M., Motesharrei, S., Mu, Q., Kalnay, E., and Li, S.: Local cooling and warming effects of forests based on satellite observations, Nature Communications, 6, http://dx.doi.org/10.1038/ncomms7603, 2015.

Li, Y., De Noblet-Ducoudré, N., Davin, E. L., Motesharrei, S., Zeng, N., Li, S., and Kalnay, E.: The role of spatial scale and background climate in the latitudinal temperature response to deforestation, Earth Syst. Dynam., 7, 167-181, https://doi.org/10.5194/esd-7-167-2016, 2016.

Li, Z.-L., Tang, B.-H., Wu, H., Ren, H., Yan, G., Wan, Z., . . . Sobrino, J. A.: Satellite-derived land surface temperature: Current status and perspectives. Remote Sens. Environ., 131, 14-37, https://doi.org/10.1016/j.rse.2012.12.008, 2013. Luyssaert, S., Jammet, M., Stoy, P. C., Estel, S., Pongratz, J., Ceschia, E., . . . Dolman, A. J.: Land management and land-cover change have impacts of similar magnitude on surface temperature, Nat. Clim. Change, 4, 389-393, http://dx.doi.org.libproxy.helsinki.fi/10.1038/nclimate2196, 2014.

Maeda, E. E., and Hurskainen, P.: Spatiotemporal characterization of land surface temperature in Mount Kilimanjaro using satellite data, Theor. Appl. Climatol., 118, 497-509, http://doi.org/10.1007/s00704-013-1082-y, 2014.

Maeda, E. E., Clark, B. J., Pellikka, P., and Siljander, M.: Modelling agricultural expansion in Kenya's Eastern Arc

1 Mountains biodiversity hotspot, Agr. Syst., 103, 609-620, http://dx.doi.org/10.1007/s00704-013-1082-y, 2010.

2 Martínez Pastur, G., Perera, A. H., Peterson, U., and Iverson, L. R.: Ecosystem Services from Forest Landscapes: An

43 Overview, in: Ecosystem Services from Forest Landscape, edited by: Perera, A., Peterson, U., Pastur, G., and Iverson,

L. Springer, https://doi.org/10.1007/978-3-319-74515-2, 2018.

45 Mendenhall, C. D., Shields-Estrada, A., Krishnaswami, A. J., and Daily, G. C.: Quantifying and sustaining biodiversity

46 in tropical agricultural landscapes, P. Natl. Acad. Sci. USA, 113, 14544-14551, https://doi-

org/10.1073/pnas.1604981113, 2016.

48 Mildrexler, D. J., Zhao, M., and Running, S. W.: A global comparison between station air temperatures and MODIS

49 land surface temperatures reveals the cooling role of forests, J. Geophys. Res., 116,

50 https://doi.org/10.1029/2010JG001486, 2011. 
https://doi.org/10.5194/bg-2021-261

Preprint. Discussion started: 21 October 2021

(c) Author(s) 2021. CC BY 4.0 License.

551 MoALF: Climate Risk Profile for Taita Taveta. Kenya County Climate Risk Profile Series, The Kenya Ministry of

552 Agriculture, Livestock and Fisheries (MoALF), Nairobi, 2016.

553 Muimba-Kankolongo, A.: Food Crop Production by Smallholder Farmers in Southern Africa, Academic Press, pp. 382,

5542018.

555 Mwalusepo, S., Massawe, E. S., Affognon, H., Okuku, G. O., Kingori, S., Mburu, P. D., . . Le Ru, B. P.: Smallholder

556 Farmers' Perspectives on Climatic Variability and Adaptation Strategies in East Africa: The Case of Mount Kilimanjaro

557 in Tanzania, Taita and Machakos Hills in Kenya, J. Earth Sci. Clim. Change, 6, http://dx.doi.org/10.4172/2157-

$558 \quad 7617.1000313,2015$.

559 Ndossi, M. I., and Avdan, U.: Application of Open Source Coding Technologies in the Production of Land Surface

560 Temperature (LST) Maps from Landsat: A PyQGIS Plugin, Remote Sens., 8, 413. https://doi.org/10.3390/rs8050413,

5612016.

562 Nemani, R., Pierce, L., and Running, S.: Developing Satellite-derived Estimates of Surface Moisture Status, J. Appl.

563 Meteorol., 32, 548-557, 1993.

564 Ong, C. K., Black, C. R., and Muthuri, C. W.: Modifying forestry and agroforestry to increase water productivity, CAB

565 Reviews: Perspectives in Agriculture, Veterinary Science, Nutrition and Natural Resources, 1,

566 https://doi.org/10.1079/PAVSNNR20061065, 2006.

567 Pellikka, P., and Hakala, E.: Climate change, in: Megatrends in Africa, edited by: Vastapuu, I., Mattlin, M., Hakala, E.,

568 and Pellikka, P., 7-14, Ministry of Foreign Affairs of Finland, 2019.

569 Pellikka, P. K., Lötjönen, M., Siljander, M., and Lens, L.: Airborne remote sensing of spatiotemporal change (1955-

570 2004) in indigenous and exotic forest cover in the Taita Hills, Kenya, Int. J. Appl. Earth Obs., 11, 221-232,

571 https://doi.org/10.1016/j.jag.2009.02.002, 2009.

572 Pellikka, P. K., Clark, B. J., Gosa, A. G., Himberg, N., Hurskainen, P., Maeda, E., . . Siljander, M.: Agricultural

573 Expansion and Its Consequences in the Taita Hills, Kenya, in: Developments in Earth Surface Processes, Vol. 16, edited

574 by: Paron, P., Olago, D., and Omuto, C.T., Elsevier, Amsterdam, 165-179, 2013.

575 Pellikka, P. K., Heikinheimo, V., Hietanen, J., Schäfer, E., Siljander, M., and Heiskanen, J.: Impact of land cover

576 change on aboveground carbon stocks in Afromontane landscape in Kenya, Appl. Geogr., 94, 178-189,

577 https://doi.org/10.1016/j.apgeog.2018.03.017, 2018. 
https://doi.org/10.5194/bg-2021-261

Preprint. Discussion started: 21 October 2021

(c) Author(s) 2021. CC BY 4.0 License.

578 Potter, K. A., Woods, H. A., and Pincebourde, S.: Microclimatic challenges in global change biology, Glob. Change

579 Biol., 19, 2932-2939, https://doi.org/10.1111/gcb.12257, 2013.

580 Prata, A. J., Caselles, V., Coll, C., Sobrino, A., and Ottlé, C.: Thermal Remote Sensing of Land Surface Temperature

581 from Satellites: Current Status and Future Prospects, Remote Sensing Reviews, 12, 175-224, https://doi.org/10.1080/02757259509532285, 1995.

583 R Core Team: RStudio: Integrated Development for R. RStudio, PBC, Boston, United States: http://www.rstudio.com/,

5842019.

585 Räsänen, M., Chung, M., Katurji, M., Pellikka, P., Rinne, J., and Katul, G. G.: Similarity in Fog and Rainfall

586 Intermittency, Geophys. Res. Lett., 45, 10691-10699, 2018.

587 Simó, G., Martínez-Villagrasa, D., Jiménez, M. A., and Cuxart, J.: Impact of the Surface-Atmosphere Variables on the

588 Relation between Air and Land Surface Temperatures, Pure Appl. Geophys., 175, 3939-3953,

589 https://doi.org/10.1007/s00024-018-1930-x, 2018.

590 Thijs, K. W., Aerts, R., van der Moortele, P., Aben, J., Musila, W., Pellikka, P., Gulinck, H., and Muys, B.: Trees in a

591 human-modified tropical landscape: Species and trait composition and potential ecosystem services, Landscape Urban

592 Plan., 144, 49-58, https://doi.org/10.1016/j.landurbplan.2015.07.015, 2015.

593 Tuure, J., Korpela, A., Hautala, M., Hakojärvi, M., Mikkola, H., Räsänen, M., Duplissy, J., Pellikka, P., Kulmala, M.,

594 Petäjä, T., and Alakukku, L.: Comparison of surface foil materials and dew collectors location in an arid area: a one-year

595 experiment in Kenya, Agr. Forest Meteorol. 276-277, 107613, https://doi.org/10.1016/j.agrformet.2019.06.012, 2019.

596 Unruh, J. D., Houghton, R. A., and Lefebvre, P. A.: Carbon storage in agroforestry: an estimate for sub-Saharan Africa,

597 Clim. Res., 3, 39-52, 1993.

598 USGS. (2017). Landsat 8 OLI and TIRS Calibration Notices: https://www.usgs.gov/land-resources/nli/landsat/landsat-

599 8-oli-and-tirs-calibration-notices, last access: 17 February 2020, 2017.

600 Wachiye, S., Merbold, L., Vesala, T., Rinne, J., Räsänen, M., Leitner, S., and Pellikka, P.: Soil greenhouse gas

601 emissions under different land-use types in savanna ecosystems of Kenya, Biogeosciences, 17, 2149-2167,

602 https://doi.org/10.5194/bg-17-2149-2020, 2020.

603 Wanderley, R. L., Dominigues, L. M., Joly, C. A., and da Rocha, H. R.: Relationship between land surface temperature

604 and fraction of anthropized area in the Atlantic forest region, Brazil, PLoS One, 14,

605 http://dx.doi.org/10.1371/journal.pone.0225443, 2019. 
https://doi.org/10.5194/bg-2021-261

Preprint. Discussion started: 21 October 2021

(c) Author(s) 2021. CC BY 4.0 License.

606 Wang, L., Lu, Y., and Yao, Y.: Comparison of Three Algorithms for the Retrieval of Land Surface Temperature from

607 Landsat 8 Images, Sensors, 19, 5049, http://dx.doi.org.libproxy.helsinki.fi/10.3390/s19225049, 2019.

608 Wild, J., Kopecký, M., Maeck, M., Sanda, M., Jankovec, J., and Haase, T.: Climate at ecologically relevant scales: A

609 new temperature and soil moisture logger for long-term microclimate measurement, Agr. Forest Meteorol., 268, 40-47,

610 https://doi.org/10.1016/j.agrformet.2018.12.018, 2019.

611 Zellweger, F., De Frenne, P., Lenoir, J., Rocchini, D., and Coomes, D.: Advances in Microclimate Ecology Arising

612 from Remote Sensing, Trends Ecol. Evol., 34, 327-341, https://doi.org/10.1016/j.tree.2018.12.012, 2019.

613 Zellweger, F., De Frenne, P., Lenoir, J., Vangansbeke, P., Verheyen, K., Bernhardt-Römermann, M., . . Coomes, D.:

614 Forest microclimate dynamics drive plant responses to warming, Science, 368, 772-775,

615 https://doi.org/10.1126/science.aba6880, 2020.

616 Zomer, R. J., Trabucco, A., Coe, R., Place, F., van Noordwijk, M., and Xu, J. C.: Trees on farms: an update and

617 reanalysis of agroforestry's global extent and socio-ecological characteristics. Working Paper 179, World Agroforestry

618 Centre (ICRAF) Southeast Asia Regional Program, Bogor, Indonesia, 2014.

619

620

Additional references in Appendix A:

621 Nobis, M., and Hunziker, U.: Automatic thresholding for hemispherical canopy-photographs based on edge detection, Agr. Forest Meteorol., 128, 243-250, https://doi.org/10.1016/j.agrformet.2004.10.002, 2005.

623 Paletto, A., and Tosi, V.: Forest canopy cover and canopy closure: comparison of assessment techniques, Eur. J. Forest

624 Res., 128, 265-272, https://dx.doi.org/10.1007/s10342-009-0262-x, 2009.

625 Pellikka, P., Seed, E. D., and King, D. J.: Modelling Deciduous Forest Ice Storm Damage Using Aerial CIR Imagery and

626 Hemispheric Photography, Can. J. Remote Sens., 26, 394-405, https://doi.org/10.1080/07038992.2000.10855271, 2000.

627 Ridler, T. W., and Calvard, S.: Picture Thresholding Using an Iterative Selection Method, IEEE T. Syst. Man Cyb., 8, 628 630-632., 1978.

629 Schleppi, P., Conedera, M., Sedivy, I., and Thimonier, A.: Correcting non-linearity and slope effects in the estimation of

630 the leaf area index of forests from hemispherical photographs, Agr. Forest Meteorol., 144, 236-242, 631 https://doi.org/10.1016/j.agrformet.2007.02.004, 2007. 
https://doi.org/10.5194/bg-2021-261

Preprint. Discussion started: 21 October 2021

(C) Author(s) 2021. CC BY 4.0 License.

(c) (i)

632 Thimonier, A., Sedivy, I., and Schleppi, P.: Estimating leaf area index in different types of mature forest stands in

633 Switzerland: a comparison of methods, Eur. J. Forest Res., 129, 543562, https://doi.org/10.1007/s10342-009-0353-8,

6342010. 